\title{
Discriminating Sources and Flowpaths of Anthropogenic Nitrogen Discharges to Florida Springs, Streams and Lakes
}

\author{
S. T. BACCHUS \\ Applied Environmental Services, LLC, P.O. Box 174, Athens, GA 30603-0174 \\ P. J. BARILE \\ Division of Marine Science, Harbor Branch Oceanographic Institution, \\ 5600 U.S. 1 North, Ft. Pierce, FL 34946
}

Key Terms: Biogeochemical Tracers, CAFOs, Harmful Algal Blooms, Invasive Species, Sewage Effluent, Stable Nitrogen Isotopes

\section{ABSTRACT}

Surface discharges of anthropogenic nutrients historically have been the focus of Florida's waterquality regulations. Groundwater contributions to eutrophication of Florida's surface waters are a more recent focus. Florida's naturally oligotrophic springs, streams, and lakes are experiencing significant anthropogenic nutrient contamination resulting from groundwater discharges with elevated nitrate. Sources of nitrate contamination to these surface-water ecosystems include sewage effluent, industrial animal waste (concentrated animal feedlot operations) and inorganic fertilizers. In this study, stable nitrogen isotope $\left(\delta^{15} \mathbf{N}\right)$ analysis of freshwater macrophytes was combined with basic knowledge of watershed and springshed land use and aquifer characteristics to provide evidence of nitrogen contamination sources and groundwater flowpaths. Selected naturally oligotrophic ecosystems included springs and a spring-run stream within the Ocala National Forest (ONF) and springs, a blackwater stream, and a sinkhole lake on or adjacent to state lands. Elevated $\delta^{15} \mathrm{~N}$ values $(\sim+8$ to $12 \%$ o $)$ in ONF macrophytes indicated nitrogen contamination from sewage effluent. Underground injections of effluent and other wastes at ONF's Alexander and Juniper Springs Recreation Areas are the sole source of contaminants flowing through the sandy, surficial aquifer at those study areas. Samples from springs on state lands indicated nitrogen contamination from various sources via regional groundwater flowpaths. At Lake Placid's state lands, a dairy-waste lagoon was the groundwater source of nitrogen contamination via the sandy, surficial aquifer. Bulow Creek $\delta^{15} \mathrm{~N}$ macrophyte values $(\sim+5$ to $8 \%$ sogested contamination from both cattle and septic tank leachate. Results indicated that uptake of anthropogenic nitrogen occurred in invasive alien and nuisance native macrophytes in the four freshwater ecosystem types evaluated.

\section{INTRODUCTION}

Sources and Discharges of Nutrient Contamination

Florida's naturally oligotrophic (nutrient-limited) surface waters and ground waters, which are characteristic of the southeastern Coastal Plain, have experienced severe and escalating nitrogen (particularly nitrate) contamination during the past 50 years (Katz et al., 1999; Toth, 2001). Nitrate can be transported readily beneath the soil zone because of its solubility and resistance to ion exchange (Fryar et al., 2000). Excessive nutrient (nitrogen and phosphorus) contamination constitutes one of the most significant water-quality problems facing the State of Florida, resulting in regulations to mitigate this problem and to protect waters of the state from further nutrient discharges. Rules adopted by the state give particular consideration to the antidegradation of waters characterized by very low nutrient concentrations, including, specifically, the protection of those waters from anthropogenic nutrient contamination (Florida Administrative Code 62-302.300 (13)). "Nutrient over-enrichment" has been used in a policy context to relate the problem of nutrient contamination to ecosystem degradation (National Research Council, 2000). For example, exceedingly low concentrations (10 ppb) of phosphorus have led to the invasion of monotypic stands of cattails and the decline of native sawgrass in the Florida Everglades (Davis, 1994).

The primary sources of bioavailable anthropogenic nitrogen entering Florida's coastal and inland waters include agricultural and urban fertilizers, human sewage effluent, and industrial animal waste. The source of industrial animal waste is referred to in state and federal 
regulations as "concentrated animal feedlot operations" (CAFOs). In Florida, dairy cows, beef cattle, and chickens are the primary producers of industrial animal wastes.

Bioavailable anthropogenic nitrogen and other contaminants discharge to Florida's coastal and inland waters as surface and underground point sources and non-point sources. Common point-source discharges from surface sources that are regulated by the Florida Department of Environmental Protection (FDEP) include discharges of municipal effluent from sewage treatment plant (STP) outfall pipes and other surface pipe discharges from industrial, commercial and municipal sources. An example of common non-point sources regulated by FDEP is stormwater runoff (overland flow), which can transport urban, agricultural and industrial nutrients to surface waters (Karr, 1990).

These surface discharges have been the primary focus with respect to nutrient loading in Florida's surface waters. Comparable attention to nutrient-laden groundwater discharges to surface waters in Florida has not occurred (Bacchus, 2001, 2002). Recently, FDEP has begun investigating the impact of land use on local and regional groundwater contributions to selected inland surface waters in Florida where a primary component is direct groundwater discharge via conduits in the regional aquifer (Scott et al., 2002).

The physical characteristics of these local and regional groundwater contributions have been described for the submarine (drowned) carbonate platform within the regional Floridan aquifer system. Both diffuse and direct submarine groundwater discharges (SGD) are known to occur along Florida's coast (summarized by Bacchus, $2000,2002)$. These discharges provide insight into the flow characteristics of the regional aquifer system. Some of the potential adverse impacts of SGD to coastal ecosystems in Florida from nutrients and other contaminants injected into the aquifer system via shallow and deep wells were addressed by Bacchus (2001, 2002). Various groundwater flowpaths of local to regional scale that may influence these SGD contributions, as well as groundwater discharges to non-marine surface waters, were described initially by Toth (1963).

Comparable diffuse and direct groundwater discharges also occur throughout the exposed carbonate platform of Florida and adjoining states comprising the southeastern Coastal Plain. Recent investigations of selected, primarily non-submerged springs in Florida have documented the degradation of water quality as nutrients originating from land-use changes are transported to the springs as subsurface discharges (Jones et al., 1996, 1997; Toth, 1999, 2001, 2003; and Toth and Fortich, 2002). As part of a multi-million dollar study of increasing groundwater eutrophication in Florida, FDEP evaluated first-magnitude springs (Scott et al., 2002, p. 6), which were reported as having an average flow of " $100 \mathrm{cfs}$ or more $(64.6 \mathrm{mgd}$ or more)."

The groundwater discharges described above are enhanced by the karstic nature of the regional carbonate Floridan aquifer system (Figure 1). The Floridan aquifer is overlain by unconfined sandy surficial aquifers throughout much of its region. The exchange of water between these surficial aquifers and the underlying, semiconfined regional aquifer has been established throughout the extent of the Floridan aquifer (Toth, 1999; Bacchus, $2000,2002)$. Therefore, these surficial aquifers are an integral part of the regional Floridan aquifer system. For the purpose of our analysis, however, two groundwater flow components are addressed: (1) local (unconfined, surficial) and (2) regional (semi-confined Floridan). No distinction is made between regional and subregional (intermediate) aquifers, with both referenced as the semiconfined regional aquifer. The consequence of nutrient contamination from these surficial aquifers and from the regional aquifer is considered in our study described below.

\section{Natural Ecosystem Characteristics}

Many of the natural ecosystems and associated native species of the southeastern Coastal Plain evolved under nutrient-limited conditions and are not adapted to abnormal anthropogenic nutrient loads (Sculthorpe, 1967; Bosserman, 1979; and Stinner, 1983). Consequently, excessive soluble nutrients become available in the water column and substrate for use by other organisms, such as invasive alien and nuisance native species of microscopic plants and macrophytes. Those conditions result in the loss of competitive advantage for desirable native species and the ultimate displacement of native species of plants and animals. In the past, alien species have been referred to as "exotic" species. Ten rare and endemic vascular plants (macrophytes) have been inventoried and suggested to be threatened by alterations in the quality and quantity of spring discharges in proximity to the springs and spring-run streams in east-central Florida (Florida Natural Areas Inventory, 2004).

Vegetative phase shifts were evident in studies comparing anthropogenic and natural sources of nutrients to aquatic ecosystems in Florida and related wetlands (Valiela et al., 1975; Dierberg and Brezonik, 1978; Stinner, 1983; and Bacchus, unpublished data). A largescale example of these vegetative phase shifts is the replacement of the dominant native saw-grass (Cladium jamaicense Crantz) by cattails (Typha spp.) in the northern Everglades, following contamination with nutrient-laden agricultural discharges (Davis, 1994; Vaithiyanathan and Richardson, 1999). The natural nutrient limitations of these ecosystems and the potential magnitude of anthropogenic sources of nutrients were demonstrated further in 


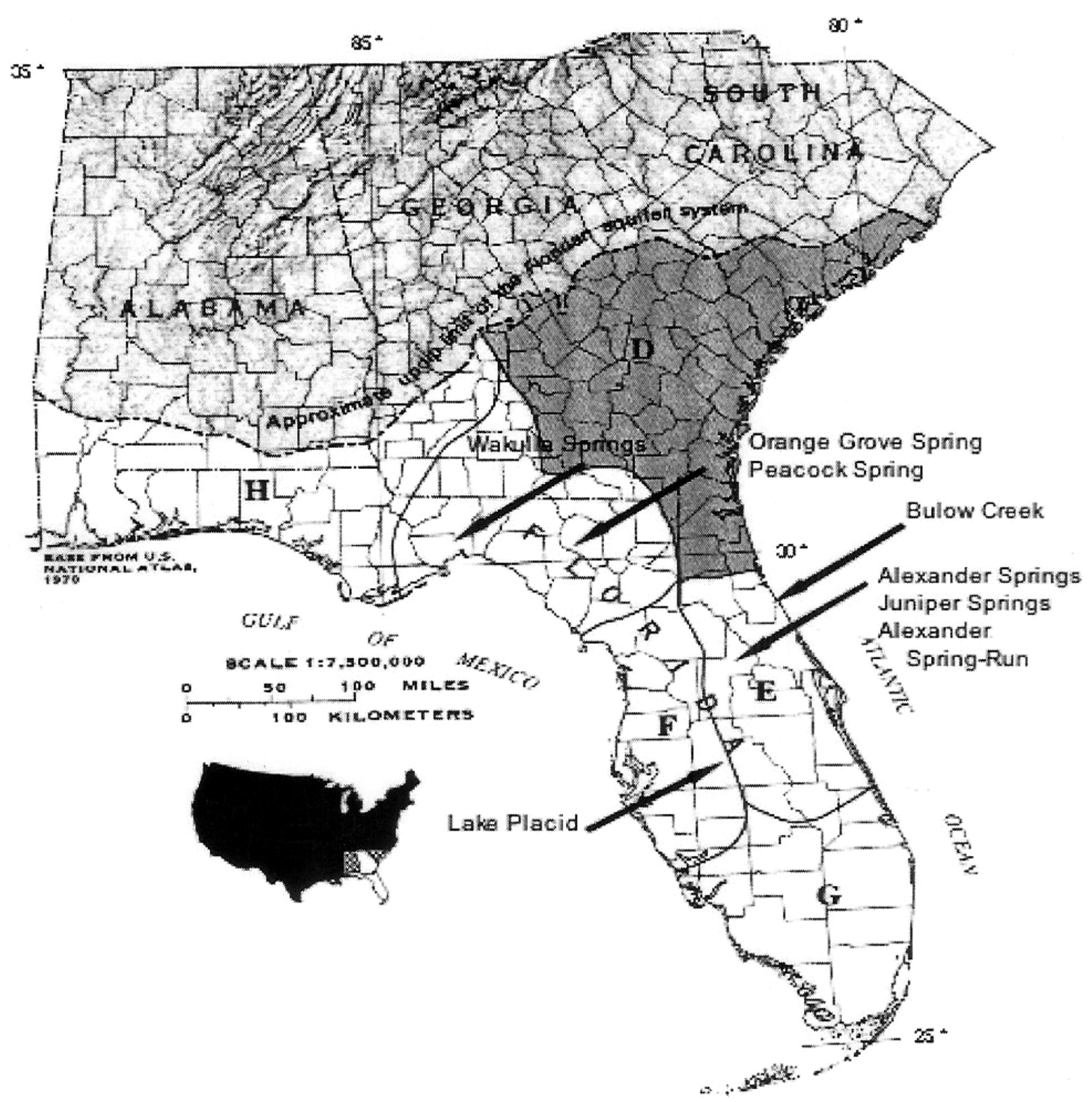

Figure 1. Areal extent of the regional Floridan aquifer system (submarine extent not shown); the six subregions designated for regional groundwater modeling (D, E, F, G, H, and unnamed subregions; from Krause and Randolph, 1989); and the general locations of the areas selected in Florida for this study.

a study that found total phosphorus 24 times greater in a depressional pond-cypress (Taxodium ascendens Brong.) dome wetland in Florida receiving surface discharges of treated sewage effluent than in comparable watershed wetlands (Stinner, 1983). In that same study, total phosphorus from inorganic fertilizers in an agroecosystem and from a white ibis rookery were only 4.0 times greater and 2.3 times greater, respectively, than total phosphorus in the comparable natural ecosystem referenced above.

In recognizing the implications of anthropogenic nitrate-nitrogen on natural ecosystems, FDEP (2000) noted that concentrations $<1 \mathrm{mg} / \mathrm{L}$ cause a shift in the balance of spring ecological communities, leading to intensified degradation of biological systems. The St. Johns River Water Management District (SJRWMD) recognizes $0.2 \mathrm{mg} / \mathrm{L}$ nitrate-nitrogen in ground water and discharge from springs as a threshold for nitrogen contamination. This threshold was established by their database (Toth, 1999). By comparison, the physiological threshold of dissolved inorganic nitrogen (nitrate + nitrite + ammonium) reported to support and saturate growth of Florida's dominant red tide organism and harmful marine macroalgae is $\sim 1.0 \mu \mathrm{M}$ 
Table 1. Freshwater macrophyte species used for stable nitrogen isotope $\left(\delta^{15} N\right)$ analysis of selected springs, spring-run and blackwater streams, and a sinkhole lake in Florida.

\begin{tabular}{|c|c|c|c|}
\hline Common Name ${ }^{1}$ & Scientific Name $^{1}$ & Growth Form & Study Area/Site ${ }^{2}$ \\
\hline Cattail & Typha spp. & rooted emergent & $\begin{array}{l}\text { AS } \\
\text { BC } \\
\text { LP1,2,4,7,9 }\end{array}$ \\
\hline Common reed & $\begin{array}{l}\text { Phragmites australis (Cav.) } \\
\text { Trin. ex Steud. }\end{array}$ & rooted emergent & LP8d \\
\hline Duckmeat & Spirodela polyrhiza (L.) Scheid. & floating-leafed aquatic & WS \\
\hline Duckweed & Lemna valdiviana Phil. & floating-leafed aquatic & $\begin{array}{l}\text { AS } \\
\text { BC } \\
\text { LP13 } \\
\text { PS } \\
\text { WS }\end{array}$ \\
\hline Eelgrass & Vallisneria americana Michx. & submersed aquatic & $\begin{array}{l}\text { AS } \\
\text { JS }\end{array}$ \\
\hline Elderberry & Sambucus canadensis $\mathrm{L}$. & rooted emergent & LP10-17 \\
\hline Eurasian water-milfoil & Myriophyllum spicatum L. & submersed aquatic & LP6 \\
\hline $\begin{array}{l}\text { Filamentous } \\
\text { algae/cyanobacteria }\end{array}$ & filamentous algae & submersed aquatic & $\begin{array}{l}\text { AS } \\
\text { BC } \\
\text { JS } \\
\text { LP8a,d,9,15 } \\
\text { OS } \\
\text { PS } \\
\text { WS }\end{array}$ \\
\hline Frog's bit & Limnobium spongia (Bosc.) Stued. & floating-leafed aquatic & LP15 \\
\hline Hydrilla & Hydrilla verticillata (L. f.) Caspary & submersed aquatic & $\begin{array}{l}\text { PS } \\
\text { WS }\end{array}$ \\
\hline Maidencane & Panicum hemitomon Schult. & rooted emergent & $\mathrm{LP} 4,5,6,8 \mathrm{a}, 16$ \\
\hline Musk-grass, stonewort & Chara sp. & submersed aquatic & OS \\
\hline Pickerelweed & Pontederia cordata $\mathrm{L}$. & rooted emergent & $\mathrm{LP} 2,8 \mathrm{~b}, 9$ \\
\hline Primrose-willow & Ludwigia peruviana (L.) Hara. & rooted emergent & LP2,6,8a,8c,9-15,17 \\
\hline Torpedo grass & Panicum repens $\mathrm{L}$. & rooted emergent & $\mathrm{LP} 1,2,7,8 \mathrm{a}$ \\
\hline Water hemlock & Cicuta mexicana Coult. \& Rose & rooted emergent & AS \\
\hline Water hyacinth & Eichhornia crassipes (Mart.) Solms & floating-leafed aquatic & $\begin{array}{l}\mathrm{BC} \\
\mathrm{WS}\end{array}$ \\
\hline Water lettuce & Pistia stratiodes $\mathrm{L}$. & floating-leafed aquatic & AS \\
\hline Yellow cow-lily & Nuphar luteum (L.) Sibth. \& Sm. & floating-leafed aquatic & $\begin{array}{l}\mathrm{LP} 3,6,8 \mathrm{a}, 8 \mathrm{~b} \\
\text { OS }\end{array}$ \\
\hline
\end{tabular}

${ }^{1}$ Nomenclature for vascular macrophytes is based on Godfrey and Wooten $(1979,1981)$.

${ }^{2}$ Study areas: AS = Alexander Springs and Spring-Run Stream (upstream of 445 bridge, 10/13/02); BC = Bulow Creek (10/24/02); JS = Juniper Springs (10/17/03); LP = Lake Placid, sites $1-17$ as shown in Figure 4 (4/8/02); OS = Orange Grove Springs $(10 / 10 / 02)$; PS $=$ Peacock Springs $(10 / 10 / 02) ;$ WS $=$ Wakulla Springs $(2 / 25 / 05)$

(summarized by Barile, 2004), illustrating the similarities between Florida's naturally nutrient-limited freshwater and marine ecosystems.

Species that replace desirable native species in Florida's freshwater ecosystems include invasive alien species of aquatic macrophytes such as water hyacinth, water lettuce, hydrilla, cyanobacteria (blue-green algae), other filamentous algae, and nuisance native species. Table 1 includes examples of invasive and nuisance macrophytes in Florida, in addition to desirable native macrophyte species, such as maidencane and pickerelweed. The invasive macrophytes become so dense in Florida's surface waters subjected to nutrient loading that the quality of swimming, boating, fishing, and other recreational opportunities is reduced or precluded. In an effort to control these invasive species, the state spends millions of dollars annually applying various herbicides. As the plants die, their decomposition results in the recycling of nutrients in the system, thus perpetuating the problem. Recognizing the wide-spread and pervasive nature of the nutrient pollution problem for surface waters (National Research Council, 1992, 2000), Congress passed the Aquatic Invasive Species Research Act (HR 1081) in 2003. Section 3 of the Act defined the term "aquatic ecosystem" as "a freshwater, marine, or estuarine environment (including inland waters and wetlands) located in the United States."

Harmful cyanobacteria blooms have become common 
in many east-central Florida and other freshwater systems (Anderson et al., 2002; Livingston, 2005; and Phlips et al., 2005). The toxins from these harmful algal blooms have been identified as the causal factor in mass death of manatee, a federally-listed endangered species with critical habitat throughout Florida (U.S. Fish and Wildlife Service, 2001), as well as other marine mammals, alligators, and numerous species of freshwater and coastal fishes and invertebrates. In addition to wildlife mortality resulting from cyanobacterial toxins, toxin-producing blooms also have been associated with sublethal adverse effects such as sexual reproduction abnormalities in alligators (Ross, 2000). The production of microcystin toxin in these systems also has threatened surface-water sources used for potable water and been associated with liver cancer in humans (Fleming et al., 2002).

\section{Stable Nitrogen Isotopes in Aquatic Systems}

Stable nitrogen isotopes $\left(\delta^{15} \mathrm{~N}\right)$ have been utilized in ecosystem studies to trace food webs and discriminate geochemical processes through biota, as well as to study pollution source contamination in biological systems (see reviews by Heaton, 1986; Peterson and Fry, 1987; Handley and Raven, 1992; and Lajtha and Michener, 1994). Specifically, $\delta^{15} \mathrm{~N}$ has been utilized to discriminate inorganic and organic nitrogen sources in aquatic foodwebs. This technique particularly is valuable when source values have been identified. The $\delta^{15} \mathrm{~N}$ of source values can be discriminated as a result of fractionation, whereby the lighter isotope, ${ }^{14} \mathrm{~N}$, is taken up preferentially in metabolic processes compared to the heavier isotope, ${ }^{15} \mathrm{~N}$. For example, where atmospheric air is used as a baseline of 0 , inorganic nitrogen fertilizer has a $\delta^{15} \mathrm{~N}$ of +1 to $3 \%$, organic nitrogen (which may include natural, fixed nitrogen in soils and manure) generally ranges from +3 to $9 \%$, and human sewage effluent ranges from $\sim+8$ to $20 \%$, depending on treatment processes (Heaton, 1986).

More recently, this method has been used in the United States to evaluate the nitrogen composition or to discriminate sources of nitrogen contamination in estuarine macrophytes (Cloern et al., 2002), marine macrophytes (Barile, 2004), and surface-water and groundwater systems (Katz et al., 1999; Battaglin et al., 2001; Kendall et al., 2001; Burns and Kendall, 2002; Chang et al., 2002; deBruyn and Rasmussen, 2002; Ashkenas et al., 2004; Pardo et al., 2004; and Wilcox et al., 2004). In spring systems within our study region, Katz et al. (1999) and Toth $(1999,2003)$ have used $\delta^{15} \mathrm{~N}$ to discriminate sources of inorganic fertilizer nitrogen from organic nitrogen, such as natural fixed nitrogen in soils and manure and residential septic tank effluent in groundwater discharges. Where overlap occurs for reported values, these values may originate from more than one nitrogen source (Chang et al., 2002). We hypothesize that $\delta^{15} \mathrm{~N}$ analysis of freshwater macrophytes, combined with basic knowledge of watershed and springshed land use and aquifer flow characteristics, can be used to discriminate nitrogen contamination sources and groundwater flowpaths for sources such as industrial animal feedlot operations, human sewage effluent, and inorganic fertilizers used in agricultural operations.

\section{STUDY AREAS AND METHODOLOGY}

This study was initiated to identify probable sources of subsurface nitrogen loading responsible for the conspicuous abundance of invasive alien and nuisance native macrophytes in selected Florida freshwater ecosystems. Stable nitrogen isotope $\left(\delta^{15} \mathrm{~N}\right)$ analysis of freshwater macrophytes was combined with basic knowledge of watershed and springshed land use and aquifer flow characteristics to evaluate the sources and flowpaths for groundwater discharges potentially containing anthropogenic nitrogen. Watershed land use included only activities located within standard land surface topographic boundaries (commonly referenced as surface-water divides) surrounding the target surface waters and capable of resulting in groundwater discharge to those target surface waters. Springshed land use included activities located beyond watershed boundaries and capable of contributing groundwater discharge to surface waters in surrounding watersheds. Groundwater flow components included sandy, surficial (local) aquifers and the underlying (regional) karst Floridan aquifer. More specific information regarding aquifer characteristics of the Floridan aquifer system in the vicinity of our study areas can be found in Rosenau and others (1977), Miller (1986), Katz and others (1999), and Toth (1999; see http://sjr.state.fl.us/programs/outreach/pubs/index.html).

Target alien species included Category I and II invasive aquatic species identified by the Florida Exotic Pest Plant Council (http://www.fleppc.org/). Both common and scientific names for macrophytes evaluated in this study are listed in Table 1; common names are used for all further references to those plants. Target Category I species included water hyacinth, hydrilla, and water lettuce. The primary target Category II species was Eurasian water-milfoil. Target species were based on those identified as becoming a problem in the Flagler County area of Bulow Creek because of increased anthropogenic nutrient discharges associated with urbanization.

A formal description of Florida's natural communities was prepared by the Florida Natural Areas Inventory and the Florida Department of Natural Resources (1990). The following naturally oligotrophic community (aquatic ecosystem) types were selected for this study: springs, spring-run stream, blackwater stream, and sinkhole lake. Criteria for selecting specific examples of these aquatic 

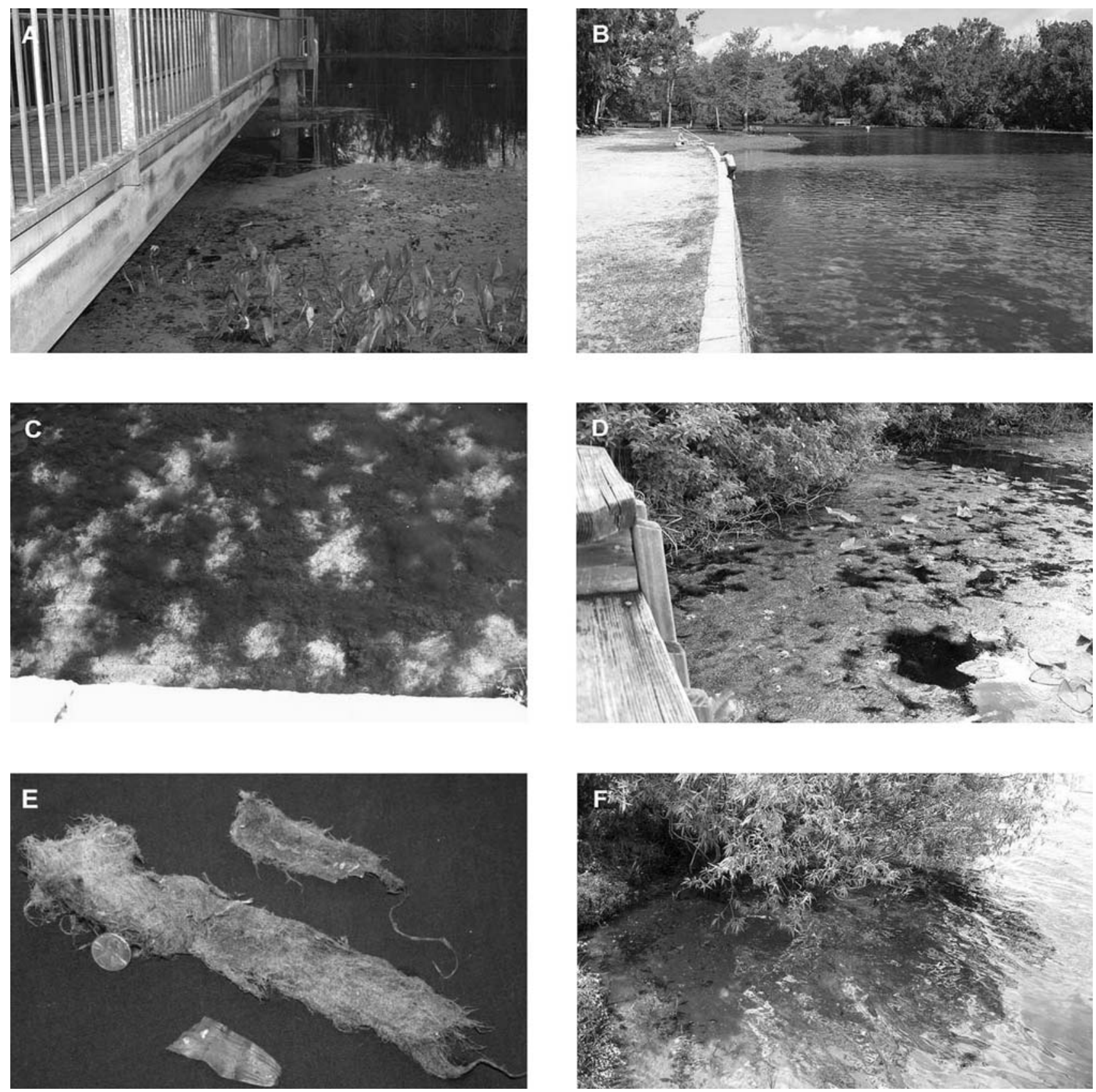

Figure 2. Representative invasive macrophytes, and benthic substrate and water column conditions at: (A) swimming area in Wakulla Springs State Park (note dense mat of floating duckweed, filamentous algae, and other invasive macrophytes); (B) Alexander Springs swimming area in ONF Recreation Area (note continuous dark area of the benthic mat formed by the harmful algal bloom, except for area of exposed sand bottom cleared by visitor use of the spring); (C) southern edge of the same swimming area (foreground), with wall located down-slope of the sewage effluent drainfield (note faint ripples at lower right corner and dark flocculent areas of invasive algae); (D) northern perimeter of the same swimming area (note lack of exposed sand substrate); (E) leaf blades of desirable native rooted submersed macrophyte (eelgrass, from ONF Salt Springs Marina) covered with thick epiphytic invasive filamentous algae (note typical appearance of leaf tip in foreground, with algae removed, and penny for scale); and (F) Wildcat Lake, ONF (note historically typical conditions of white sand bottom lacking macrophytes).

ecosystem types included a relatively protected, undeveloped watershed and springshed surrounding or adjacent to the study areas; the presence of abundant invasive macrophytes; and personal knowledge of historic, pre-invasion conditions. The study areas and sample collection sites selected for the study are described below. Representative invasive macrophytes, and benthic substrate and water column conditions at selected study areas and comparative sites are shown in Figure 2A-F. 


\section{Springs and Spring-Run Stream Selected in the Ocala National Forest and State Lands}

The relative locations for the springs (Alexander and Juniper Springs) and spring-run stream (Alexander Spring-Run) selected as study areas in the Ocala National Forest (ONF) are shown in Figure 1. Also included in Figure 1 are the relative locations of springs selected as study areas on state lands (Orange Grove, Peacock, and Wakulla Springs).

Alexander and Juniper Springs and Alexander Spring-Run

Surrounding Alexander Springs and immediately downstream, the waters are overgrown with dense macrophytes composed primarily of invasive nuisance and alien species of algae and vascular plants, and much of the natural stream bed is covered by a thick dark layer of organic ooze. These symptoms are indicative of chronic discharges of anthropogenic nutrients to the formerly pristine, oligotrophic Alexander Springs and Spring-Run. These aquatic systems, located in ONF (Lake County), provided an ideal study area, based on the following factors: (1) extensive undeveloped watershed within ONF; (2) recent water-quality data from the Floridan aquifer suggesting relatively limited anthropogenic nutrients contributed from the deep, regional aquifer source representing the springshed (Scott et al., 2002); and (3) previous observations of the ecosystem condition since the 1960s, prior to the shift to dominance by invasive macrophyte species (Bacchus, unpublished data).

The FDEP report on first-magnitude springs of Florida (Scott et al., 2002) included some erroneous and misleading information in the description of Alexander Springs. For example, the spring is not owned by ONF, as stated in the report. The U.S. Forest Service only manages the lands surrounding Alexander Springs, and the U.S. Forest Service land immediately surrounding Alexander Springs has been developed and is being operated as a private concession. The report also indicates that "native aquatic grasses are plentiful," and the "bottom is mostly sandy" (Scott et al., 2002, p. 85). Virtually no native aquatic grasses or other native species occurred at Alexander Springs at the time of that study through the present, and little of the originally sandy bottom is visible because of the extensive noxious filamentous algae (Figure $2 \mathrm{~B}$ and $\mathrm{C}$ ) and organic ooze.

No data were available from the FDEP study for Juniper, Orange Grove, or Peacock Springs, because they are not first-magnitude springs. Juniper Springs is located within the same springshed as Alexander Springs, and is $\sim 18 \mathrm{~km}(\sim 11 \mathrm{mi})$ northwest of Alexander Springs, in Marion County. Juniper Springs is exhibiting early signs of nutrification, based on the recent abnormally dense growth of native macrophytes and epiphytic filamentous algae. Similar epiphytic algae has covered and killed these desirable native plants at Alexander Springs.

\section{Orange Grove, Peacock and Wakulla Springs}

Orange Grove and Peacock Springs are located in Peacock Springs State Recreation Area, Suwannee County, $\sim 3 \mathrm{~km}(\sim 2 \mathrm{mi})$ north of the Suwannee River. Peacock Springs is the headwaters of Peacock Slough and is less than $2 \mathrm{~km}(1 \mathrm{mi})$ from Orange Grove Springs. That recreation area has no facilities with underground discharges. Although the area immediately surrounding the springs is densely wooded, and primarily in a natural state, the springshed includes both agricultural and industrial animal land uses, combined with industrialscale irrigation. A portion of the extensive subterranean karst conduits associated with Peacock Springs has been mapped by cave divers. The general extent of those conduits are shown in Figure 3, in comparison with karst conduits in other spring systems mapped by cave divers in Florida as examples of potential flowpaths and springshed areas that may contribute to subsurface nutrient discharge from the Floridan aquifer.

Wakulla Springs and the upper $5 \mathrm{~km}(3 \mathrm{mi})$ of the Wakulla River are located in Wakulla Springs State Park, Wakulla County, and designated as a "protected wildlife sanctuary" (Scott et al., 2002, p. 134). The watershed immediately surrounding Wakulla Springs primarily is in a naturally-vegetated state. Neither the watershed nor the springshed for Wakulla Springs contains industrial feedlot operations. Two municipal sewage treatment plants and associated effluent spray fields are located within different watersheds, but the same springshed, $\sim 18 \mathrm{~km}(\sim 11 \mathrm{mi})$ north-northwest and north-northeast of Wakulla Springs, in Leon County.

The northwestern sewage treatment plant and effluent spray field are located $\sim 2 \mathrm{~km}(\sim 1 \mathrm{mi})$ west of the Munson Slough watershed. Discharge at the existing wastewater treatment facility is reported as having " 27.5 MGD annual average daily flow," with land application of the reclaimed water "limited to 19.79 MGD" prior to completion of additional areas for land application (FDEP Permit Notice FLA 010139, FLA 010140, File FLA 183768-001-DW1R, 8/99). That watershed receives considerable stormwater runoff from surrounding areas in the watershed. Recent dye-tracer studies have documented rapid flow through karst conduits in the underlying regional Floridan aquifer (Davies et al., 2004; Hazlett et al., 2004; and Kincaid et al., 2004), illustrating the significance of springshed contributions.

Wakulla Springs was described in the FDEP report as one of the largest and most dramatic of Florida's springs. Hydrilla was reported as previously covering much of the spring pool and adjacent river bottom prior to removal by 


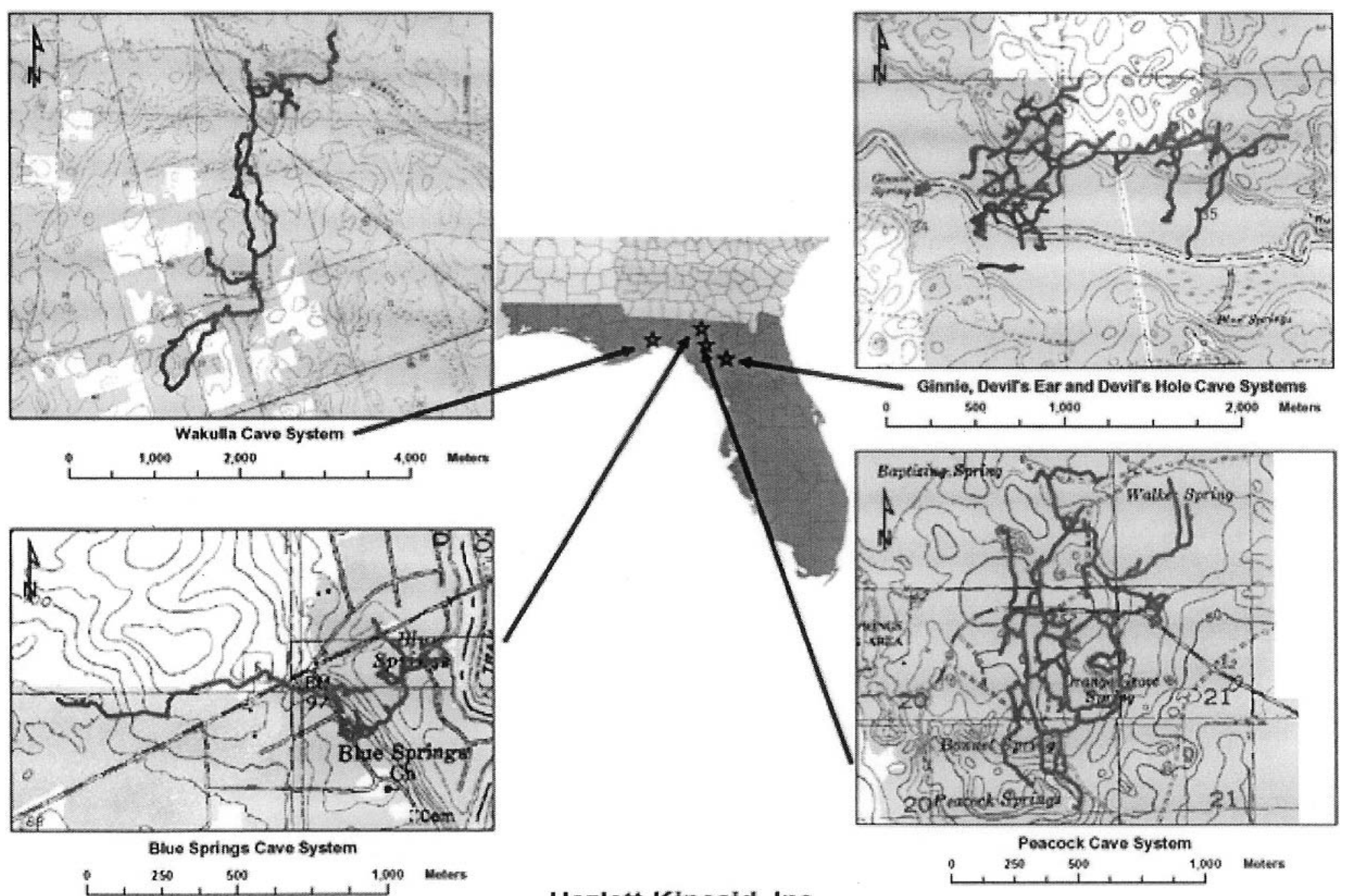

Hazlett Kincaid. Inc.

Figure 3. Submerged karst conduit networks in the Floridan aquifer associated with Peacock and Wakulla Springs, and similar Florida springs that have been mapped as cave systems (Hazlett Kincaid, Inc., unpublished).

divers prior to release of the FDEP report. The FDEP report describes the Wakulla River as "choked with this exotic invasive plant species" (Scott et al., 2002, p. 132).

At the time of the 2005 sample collections for our study, hydrilla had re-invaded the spring pool. Hydrilla had not invaded Wakulla Springs or the upper reaches of the Wakulla River in the 1960 s, but was present by the late 1970s or early 1980s (Bacchus, unpublished data). The City of Tallahassee's municipal sewage treatment plant and spray field began operating prior to the invasion and proliferation of hydrilla in Wakulla Springs and immediately downstream.

\section{Blackwater Stream in the Tomoka Marsh Aquatic Preserve}

Bulow Creek is a shallow meandering blackwater stream in the northwestern portion of the Tomoka Marsh Aquatic Preserve in Flagler County and is designated "Outstanding Florida Waters." Bulow Creek and the Aquatic Preserve are shown at http://www.dep.state.fl.us/ coastal/downloads/maps/default.htm with associated state parks. Bulow Plantation Ruins State Historical Site is shown as the northern boundary of Bulow Creek State Park on that map. Bulow Creek, bounded by John Anderson Highway on the east and Old Kings Road on the west, is located within the watershed for the Tomoka River, also "Outstanding Florida Waters," and is a manatee sanctuary. From its origin in the forested wetlands of Graham Swamp to the north, Bulow Creek flows south for $\sim 6.5 \mathrm{~km}(\sim 4 \mathrm{mi})$, under Walter Boardman Lane, meandering to its confluence with the Halifax and Tomoka Rivers at Tomoka Basin and the Tomoka State Park, as shown in the FDEP Aquatic Preserve map. The banks of Bulow Creek are bordered by floodplain forests with native species along the upper reaches. Increasing expanses of freshwater marsh vegetation grade into tidal marsh, dominated by black needle rush (Juncus roemerianus Scheele) in the lower reaches of Bulow Creek (Florida Department of Natural Resources, 1990).

Relevant management issues and threats identified in the FDEP Management Plan include protection of manatee habitat and motor boat control, cumulative impacts to water quality associated with point and nonpoint sources of pollution, restoration of disturbed areas, control of alien plant species, and growth management 
(Florida Department of Natural Resources, 1990). Large tracts of naturally vegetated (and densely forested) areas still occur in Flagler County, but rapid urbanization of that land is occurring. Sensitive aquatic systems in Flagler County have been susceptible to the invasion and spread of alien plants, partly because of lack of information available to the public. These include areas within the Tomoka Marsh Aquatic Preserve and Tomoka Basin, the Bulow Creek system, and the Halifax River/ Intracoastal Waterway. Although the Tomoka Marsh Aquatic Preserve and waters within Tomoka State Park were designated as "Outstanding Florida Waters" in 1979 and 1991, respectively, alien species of macrophytes have invaded and proliferated to the extent that they restrict recreational swimming and boating activities in parts of these waters (Bacchus, unpublished data).

During an inspection of Bulow Creek by boat in 2002, isolated dense patches of duckweed, water hyacinths, and filamentous algae were observed at discrete locations in the northern reach of Bulow Creek, in Flagler County. One patch, primarily composed of water hyacinths, occurred along the west side of the channel at the mouth of a small tributary to Bulow Creek, $1.6 \mathrm{~km}(1 \mathrm{mi})$ north (upstream) of the state historical site and $\sim 2.5 \mathrm{~km}$ $(\sim 1.5 \mathrm{mi})$ east of a cattle operation and open mine pit in the Bulow Creek flood plain. A second patch, composed of duckweed, water hyacinths, and filamentous algae, occurred on the east side of the channel $\sim 1.6 \mathrm{~km}(\sim 1 \mathrm{mi})$ south of the state historical site and $\sim 120 \mathrm{~m}(\sim 400 \mathrm{ft})$ east of a single-family residence. Similar patches of invasive macrophytes were not observed in the Flagler County portion of Bulow Creek.

\section{Sinkhole Lake in Central Florida}

Lake Placid, formerly known as Lake Childs, is a natural sinkhole lake located in west-central Highlands County (Figure 1). It extends $\sim 5 \mathrm{~km}(\sim 3 \mathrm{mi})$ along the

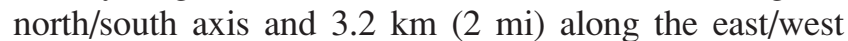
axis. The limited residential development associated with the lake (predominantly single-family residences) was established primarily from the 1950s through the 1970s and is clustered in the northeastern and northwestern portions of the watershed. The northern and eastern portions of the watershed include citrus groves and land on which citrus previously was grown. The majority of the southern portion of the Lake Placid watershed remains naturally vegetated, containing both forested seepage streams and wetlands, and sandhill uplands. These areas include the state-owned Tobler Tract (from west of Placid View Drive, east to Highway 17/railroad) and Archbold Biological Station south of Lake Annie (Figure 4).

Historically, Lake Placid was oligotrophic, as is characteristic of natural sinkhole lakes in Florida (Florida

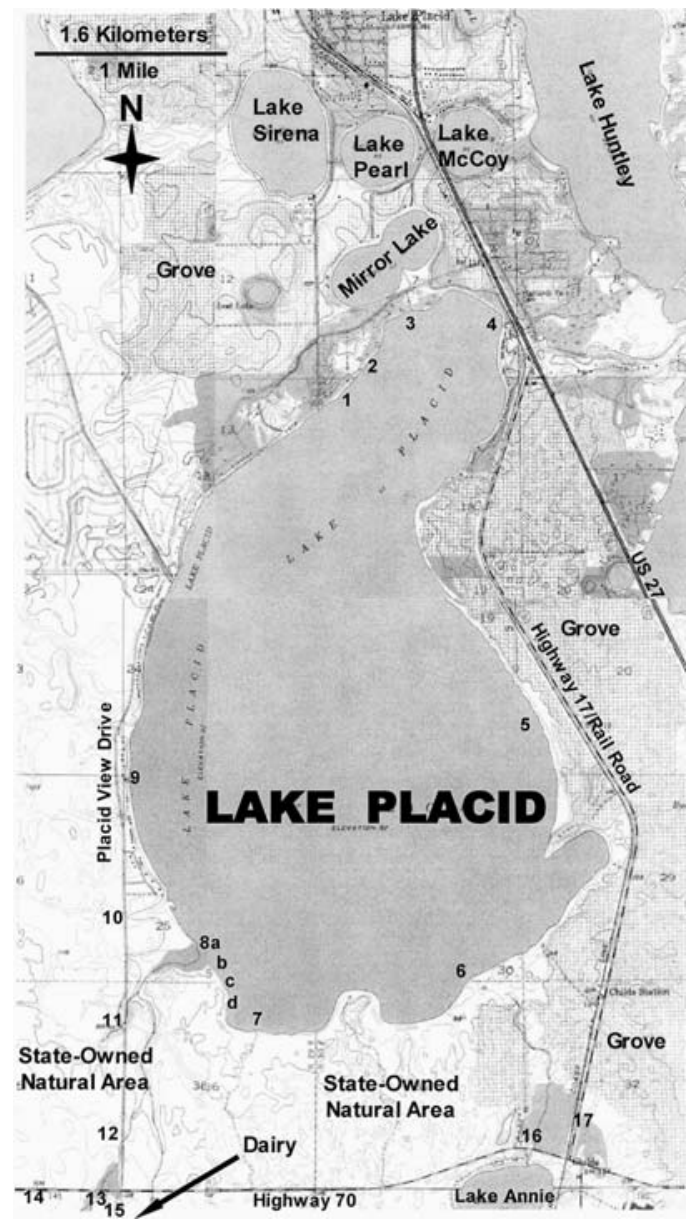

Figure 4. Map of macrophyte sample collection sites for Lake Placid.

Natural Areas Inventory and Florida Department of Natural Resources, 1990). Within the last decade, invasive macrophytes became established and proliferated in various areas of Lake Placid's littoral zone (Bacchus, unpublished data).

A series of unpublished reports prepared by the Highlands Soil and Water Conservation District describe the water-quality problems that were reported as early as April 26, 1999. A report by that date indicated that nutrient levels in stormwater from the industrial dairy operation upgradient of Lake Placid were "comparable with that commonly observed in raw sewage" and "well in excess of state water quality standards for any lake in Florida" (Ford, 2001, p. 1).

Ford (2001) described nutrient levels that were in excess of those possible from natural drainage. Ford's report also described bacterial results that were alarming, with total and fecal coliform values at the central branch under Highway 70 and at the mouth of the tributary to Lake Placid that were too numerous to count (reported as $>80,000 \mathrm{cfu} / 100 \mathrm{~mL}$ ) and total coliform values of 38,000 $\mathrm{cfu} / 100 \mathrm{~mL}$ at the west branch. The declining water 
transparencies and increased algal blooms were attributed to "loading of nutrients to the lake," and was described as a "large scale violation of the FDEP 62-302 surface water-quality standards" (Ford, 2001, p. 2).

A subsequent report (Ford, 2002) revealed that the water-quality problems were observed initially by lakefront residents in July 2001. Numerous extensive harmful algal blooms occurred following the waterquality problems observed that summer. Ammonia and total coliform bacteria levels were described as being in excess of state water-quality standards where flows were entering Lake Placid from the tributary leading from the industrial dairy operation to the southern end of the lake. That report also indicated that during a meeting related to the problem in December 2001, FDEP representatives indicated that they did not feel that the dairy was violating surface water-quality criteria (Ford, 2002, p. 2).

Water-quality monitoring conducted by the Highlands County Lake Management Program in Lake Placid and upstream in the tributary leading from the industrial dairy operation revealed that "extremely high levels of nutrients and bacteria, well in excess of FDEP 62302.530 limits were originating from drainage south of State Road 70, in the vicinity of Posey Dairy" with water-quality declines continuing for six months since the initial decline of water quality in July 2001 (Ford, 2002, p. 2). The natural tributary included in the water-quality monitoring by the Highlands Soil and Water Conservation District is part of the state-owned Tobler Tract, a densely forested natural area located between the industrial dairy operation upstream and Lake Placid.

Correspondence from Keith Kleinmann, FDEP, dated March 29, 2002, stated that the berms constructed on the dairy in September 2001 and the extension constructed in February 2002 were intact and functioning as intended, and that there was no discharge from the dairy during the inspection by FDEP inspector E. J. Jackson on March 27, 2002. On April 8, 2002, the macrophyte samples for our study were collected from the Lake Placid study area. A significant and constant discharge of ground water as seepage flow was observed at the base of the sandy "berm" that had been constructed in the upper reach of the natural tributary, in an effort to block stormwater runoff from the dairy site.

On January 28, 2002, FDEP prepared an Administrative Agreement to allow the continued operation of the dairy. That agreement stated that the dairy had 320 cows, but was allowed to maintain a herd size as great as 850 cows.

\section{Sample Collection and Stable Nitrogen Isotope Analysis of Freshwater Macrophytes}

The species and growth forms (e.g., rooted, floating) of freshwater macrophytes varied among the study areas described above, and determined which species could be collected for $\delta^{15} \mathrm{~N}$ analysis. Table 1 includes the common and scientific names, plant growth forms, and sample dates for each study area and sample collection site. The common name will be used for all further reference to the plants sampled for analysis. At the springs, submersed and floating aquatic vascular and non-vascular plants were collected for analysis from the still, littoral zone waters.

At Orange Grove Spring, one species of rooted, aquatic macrophyte with floating leaves (yellow cow-lily) also occurred in the littoral zone, and was collected for analysis. For Alexander Spring-Run, Bulow Creek, and Lake Placid, emergent, submersed, and floating aquatic species were collected for analysis from the littoral zone. Leaves from two woody emergent species in the littoral zone of the Lake Placid tributary (common reed and elderberry) and one woody emergent species in the littoral zone of Alexander Spring-Run (water hemlock) also were collected and analyzed. In the shallow channel of Alexander Spring-Run's upper reaches, dense stands of filamentous algae were anchored on both mineral substrate (e.g., carbonate rock) and on rooted, submersed native vascular macrophytes (eelgrass). Macrophyte samples from those shallow, flowing-water areas were collected and evaluated with littoral zone samples from this location.

Because the Lake Placid study area included three types of potential sources for anthropogenic nitrogen contamination (feedlot manure, septic tank effluent, and inorganic fertilizers) in surficial ground water at various locations, numerous sample sites were required there (1-17, as shown in Figure 4). Samples were collected from various sites within the littoral zone of Lake Placid, from small, natural tributaries near the southern end of the lake, and from the dairy-waste lagoon in the upper reach of one of those tributaries. Sample sites were selected based on areas with uncharacteristically dense stands of macrophytes and comparison areas. Sites were associated with a lakeside conference center and homes (Sites 1 and 9, respectively); former/existing orange groves (Sites 4 and 5, respectively); naturally-vegetated shoreline without homes, groves or industry (Sites 2 and 3 ), including the state-owned Tobler Tract natural area (Sites 6-8, 10-12, 16 and 17); and the dairy operation south of the lake (Sites 1315). The invasive macrophytes at Site 8 were so expansive that four subsites $(8 \mathrm{a}-\mathrm{d})$ were sampled at that location.

With the exception of Wakulla Springs and two potential sources at Bulow Creek, the remaining study areas included a single potential source of anthropogenic nitrogen contamination via the surficial aquifer. Because fewer sample sites were required at those study areas and the sample sites were in closer proximity than those at Lake Placid, data for the remaining study areas were not 
reported by individual sample sites, but were compiled for each study area.

Samples consisted of representative subsamples from three plants for each species sampled. The initial subsamples (2002) were collected from the entire watercolumn portion of each submersed and floating aquatic species (e.g., leaves, stems, and roots, except for roots of macrophytes growing in the bottom substrate). For extremely small plants (e.g., duckweed, Lemna minor), $\sim 12$ entire plants were required for each sample. For emergent species with only leaves extending above the water, and emergent species with woody stems, only leaves were collected for analysis. For plants with elongated, strap-like leaves (e.g., cattails), only the apical portion $(\sim 15 \mathrm{~cm})$ was collected. Entire leaves were collected for all other emergent macrophytes.

After collection, the plant material was held in a sealed cooler with ice during transport. After transport $(<12$ hours), samples were rinsed with deionized water, sorted, and combined into a composite sample for each species. The composite samples were dried for 48 hours at $60^{\circ} \mathrm{C}$. Dried tissue was ground to a fine powder with a mortar and pestle and stored in labeled vials until analysis for stable nitrogen isotope ratios, using a Carlo-Erba N/A 1500 Elemental Analyzer and a VG Isomass mass spectrometer with Dumas combustion. Dried samples from subsequent samples, which were not analyzed promptly after drying, were frozen until analysis. The initial 100 samples were divided into sample replicates prior to transfer to the laboratory, with samples analyzed in duplicate to test for analytical precision $( \pm 0.02)$. Based on those results, subsequent samples were not subdivided into sample replicates $(n=2-4)$. The standard used for $\delta^{15} \mathrm{~N}$ analysis was $\mathrm{N}_{2}$ in air. The values for $\delta^{15} \mathrm{~N}(\%)$ were calculated as $\left[\left(\mathrm{R}_{\text {sample }} / \mathrm{R}_{\text {standard }}\right)-1\right] \times$ $10^{3}$, where $R$ is equal to ${ }^{15} \mathrm{~N} /{ }^{14} \mathrm{~N}$.

Data from initial samples from this study and from subsequent data (Bacchus, unpublished) suggested that $\delta^{15} \mathrm{~N}$ values may vary in different plant tissue (e.g., roots vs. leaves) for the same location and sample event. Therefore, leaf samples from species with dense watercolumn root systems (i.e., water lettuce and water hyacinth) were not combined with root samples after the 2002 sample period. Evaluations of Lake Placid sites were made by combining the analytical results for all species from each respective sample collection site.

\section{RESULTS AND DISCUSSION}

\section{Ocala National Forest}

Alexander Springs and Spring-Run

Results of FDEP's single-point water-quality sample events led to agency conclusions that all ground water discharging at Alexander Springs was low in nutrients and lacking bacteriological contaminants (Thorsen, 2002). Samples in the FDEP study were collected by attaching weights to tubing "which was then lowered into the spring vent opening, ensuring the intake line was not influenced by surrounding surface water" (Scott et al., 2002, p. 13). A different FDEP sampling methodology occurred at Wakulla and Homosassa Springs, where samples were collected from pre-set pipes running into the cave systems containing the spring vents (Scott et al., 2002). The sampling methodology in the FDEP study ensured that results were indicative only of water from the spring's primary discharge conduit in the deeper, Floridan aquifer and did not reflect discharges from the overlying sandy surficial (local) aquifer.

The FDEP report included results for a single sample collected on September 12, 2001, with values for unfiltered and filtered $\mathrm{NO}_{3}+\mathrm{NO}_{2}$ samples, reported as 0.04 and $0.044 \mathrm{mg} / \mathrm{L}$ (total nitrogen), and for unfiltered and filtered $\mathrm{NH}_{3}+\mathrm{NH}_{4}$ samples, reported as 0.01 and $0.01 \mathrm{mg} / \mathrm{L}$ (total ammonia), respectively. The latter values represented the method detection limits. Previous water samples collected at Alexander Springs in 1946 and 1972 did not include values for those parameters, except for a value of $0.03 \mathrm{mg} / \mathrm{L}$ for $\mathrm{NO}_{3}+\mathrm{NO}_{2}$. A similar, single point sample was collected at the Alexander Springs vent on July 18, 1995, in the study conducted by the SJRWMD (Toth, 1999). The nitrate-nitrogen concentration for that sample was $0.07 \mathrm{mg} / \mathrm{L}$. The samples from both of those studies were below the $0.2 \mathrm{mg} / \mathrm{L}$ threshold that was used to identify elevated nitrate-nitrogen in the water samples (Toth, 1999).

Bacterial results from the FDEP study included Escherichia coli, Enterococci, fecal coliform, and total coliform, and have been used by the U.S. Forest Service as a determination that the public swimming area surrounding the spring and the down-stream waters (Alexander Spring-Run) were free from bacterial contamination indicative of human sewage (Thorsen, 2002, and unpublished records). All of the bacteriological samples collected from Alexander Springs in the FDEP study, however, exceeded the holding time limit. Therefore, those results were not reliable.

Elevated $\delta^{15} \mathrm{~N}$ values $(+8$ to $12 \%$ ) in macrophytes from Alexander Springs and Spring-Run (Figure 5) in our study were similar to $\delta^{15} \mathrm{~N}$ values $(+8.7$ to $9.9 \%$ ) in macroalgae from sewage-polluted coastal areas, such as the east-central Florida coast and Boston Harbor (Barile, 2004). The lowest values of $\sim+6$ to $7 \%$ in the eastcentral Florida coastal study "were measured in October and December, but are still within the ranges reported for nearby sewage nitrogen sources" (Barile, 2004). The total nitrogen load for the two counties included in the coastal east-central Florida study by Barile (2004) was 1.94 tons/day, based on information from agency records. 


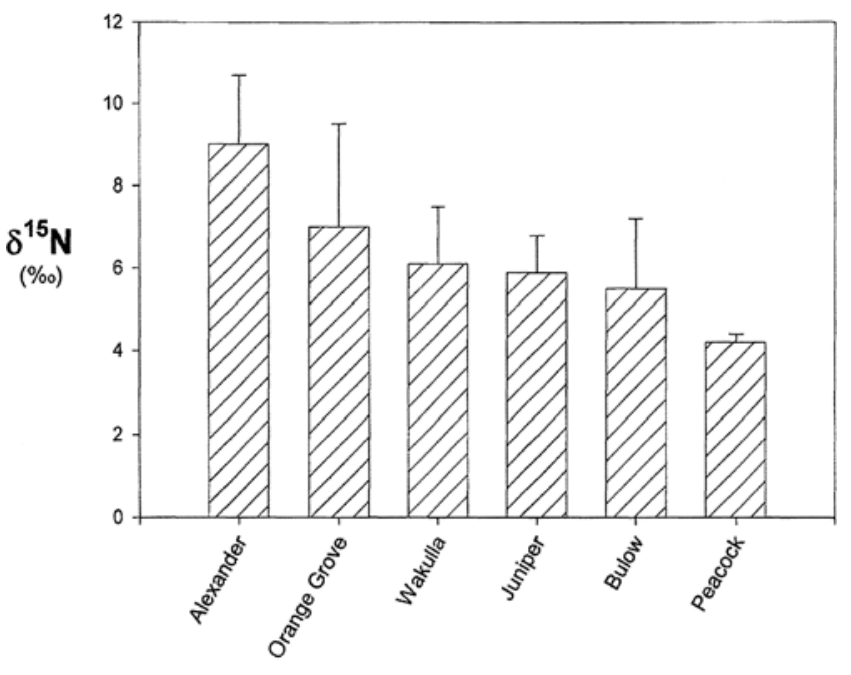

Study Area

Figure 5. Stable nitrogen isotope values $\left(\delta^{15} \mathrm{~N}\right.$ mean $\left.\pm \mathrm{SD}\right)$ for macrophytes collected from Alexander, Juniper, Orange Grove, Peacock, and Wakulla Springs; Alexander Spring-Run; and Bulow Creek.

Therefore, the results for Alexander Springs suggest that human sewage effluent was the dominant source of nitrogen supporting the growth of the invasive macrophytes in the ecosystems at this study area surrounding the spring.

The extensive harmful algal bloom throughout the Alexander Springs swimming area was re-sampled on October 21, 2004, as a comparison to the original samples. The $\delta^{15} \mathrm{~N}$ value $(+10.2 \%)$ for filamentous macroalgae was comparable to the original values for Alexander Springs and Spring-Run. All samples collected at this study area were collected during the season when the swimming area is least used by swimmers and waders. Those elevated $\delta^{15} \mathrm{~N}$ values are consistent with $\delta^{15} \mathrm{~N}$ values reported by Toth (1999) for water samples from nearby springs and watersheds contaminated with nitrogen from septic tank effluent.

The extent of the harmful algal bloom in the Alexander Springs swimming area is represented by the dark area in Figure 2B, and comprises $\sim 90$ percent of the swimming area. Attempts by visitors to avoid contact with the area of invasive macrophytes have been observed during each inspection of Alexander Springs for the past four years. Based on observations during inspections and sampling, swimmers and waders avoided the area where the flocculent algae and other invasive macrophytes were. That limited area is the light-colored area (bare sand) in Figure 2B. That area is located near the steps entering the southwestern portion of the swimming area where the visitor is seated. Figure 2D illustrates the magnitude of the harmful algal bloom in the northern perimeter of the swimming area, which is not used by swimmers or waders. No exposed sand substrate is visible in that area.

The watershed surrounding this study area is comprised of the ONF, with the only development being the U.S. Forest Service's Alexander Springs Recreation Area and commercial concession buildings. Those conditions suggest a single anthropogenic source of contaminant discharge to those ecosystems from the surficial aquifer. Those conditions also minimize the potential for contaminant introduction via the deeper, regional aquifer system that was sampled by the SJRWMD (Toth, 1999) and FDEP (Scott et al., 2002).

The drainfield at the recreation area includes underground injection pipes that discharge sewage effluent and other fluids (e.g., grey water) and solids from the Alexander Springs Recreation Area camping locations and commercial concession buildings. The land-surface elevation of the drainfield is $\sim 13 \mathrm{~m}(\sim 40 \mathrm{ft})$ higher than the land-surface elevation on the south side of the swimming area. In Florida's sandy, surficial aquifers, the water table generally is near land surface at low elevations, but is regarded to be a subdued reflection of the topography at higher elevations (Toth, 1999).

The drainfield is located $\sim 500 \mathrm{~m}(\sim 1500 \mathrm{ft})$ southwest of the swimming area, within the "buffer area" identified by the Florida Natural Areas Inventory (2004) for the protection of rare plant and animal species and rare wetland communities associated with Alexander Springs and Spring-Run. Several of the animal species are listed by the state as threatened or species of special concern, and four endangered vascular macrophytes, including endemic species, are known to have been associated with Alexander Spring and Spring-Run (Florida Natural Areas Inventory, 2004). Walsh (2001) provides more information for some of the rare and endemic species that have been reported from Alexander and other spring systems in Florida.

An enlarged view of the extensive invasive filamentous algae in the swimming area is shown as dark flocculent areas in Figure 2C, with faint ripples in the lower right corner. The ripples suggest surficial groundwater discharge and are consistent with the thick clumps of invasive algae along the shoreline wall downgradient of the recreation area drainfield, based on land-surface elevations. The image in that figure was taken at the southeastern end of the wall depicted in Figure 2B. The algae is most concentrated adjacent to the wall at that location. Historically the swimming area contained no macrophytic algae, as was the case for similar Florida springs evaluated in this study and elsewhere in Florida (Florida Natural Areas Inventory and Florida Department of Natural Resources, 1990; Bacchus, unpublished data).

Fogg et al. (1998, p. 422) documented that, in "contrast to the other source types which are more areally extensive, a septic tank is a point source that is itself heterogeneous," 
but the $\delta^{15} \mathrm{~N}$ values of the water samples "remain fairly constant with depth after reaching the water table $(\sim 11$ m)." That conclusion was based on their sample collection borehole "drilled between two leach lines spaced $7.5 \mathrm{~m}$ apart in the septic tank drainfield," which suggested that "solute plumes emanating from each drain line did not spread far enough horizontally to intersect the borehole location until a substantial depth was reached" (Fogg et al., 1998, p. 422). That depth was reported as $\sim 6 \mathrm{~m}$ and is similar to the depth to the water table reported at the Alexander Springs drainfield.

The $\delta^{15} \mathrm{~N}$ values of water samples from boreholes associated with onsite sewage disposal sources in the study by Fogg et al. (1998) approximated the lower values for sewage effluent provided by Heaton (1986), and were consistent with the values of our macrophyte samples from the ONF study areas (Figure 5). The combined $\delta^{15} \mathrm{~N}$ values for macrophytes from Alexander Springs and Spring-Run shown in Figure 5 were consistent with the $+8.6 \%$ and $+8.9 \%$ o $\delta^{15} \mathrm{~N}$ values for water samples collected from the spring vents at Wekiva and Ponce de Leon Springs, respectively, which were attributed to contamination by sewage, animal waste, or a combination of both (Toth, 1999).

Wekiva and Ponce de Leon Springs are surrounded by state lands, primarily composed of natural forested areas. The springsheds for those two springs are urbanized, with additional forested areas, and generally lack industrial animal feed-lot operations. Those land-use characteristics, combined with the rapidly increasing underground injection of sewage effluent in Florida, suggests that the source of nitrogen at Wekiva and Ponce de Leon Springs is sewage effluent rather than animal waste. Our Alexander Springs/ Spring-Run study area is $\sim 20 \mathrm{~km}(\sim 12 \mathrm{mi})$ west of Ponce de Leon Springs and $\sim 43 \mathrm{~km}(\sim 27 \mathrm{mi})$ north of Wekiva Springs (see the Figure 2 location map from Toth, 1999).

Macrophyte taxa and growth forms at this Alexander Springs/Spring-Run study area have shifted from the historic sparse, rooted, native submersed aquatic species (eelgrass), without epiphytic macroalgae, to opportunistic invasive macrophytes. These invasive, primarily alien species are not rooted in the substrate, and thus derive all nutrients from the water column (e.g., duckweed, filamentous algae, hydrilla, water hyacinths, and water lettuce). This shift in taxa and growth forms, combined with the abundance and location of opportunistic invasive and alien macrophytes in this study area, are consistent with anthropogenic nutrient-loading. The range in $\delta^{15} \mathrm{~N}$ values at this study area may be attributed to differences in uptake by different species (rooted vs. floating aquatics), or to the U.S. Forest Service's conversion from a package STP to sewage treatment by a septic tank drainfield. The extent of the adverse impact on rare and endemic species from the combined nitrogen contamination and shift to invasive macrophytes has not been determined.
The conditions described above, in conjunction with comparably elevated $\delta^{15} \mathrm{~N}$ values from multiple sample events at this study area, support the conclusion that groundwater discharges from the sandy, surficial aquifer on the southern side of the swimming area are the primary source of nitrogen contamination in Alexander Springs and Spring-Run. The ripples in the lower right corner of Figure $2 \mathrm{C}$ also suggest that surficial groundwater discharge is occurring at discrete points, in addition to diffuse surficial aquifer discharges throughout the shallow swimming area.

\section{Juniper Springs}

At Juniper Springs, the other ONF spring study area evaluated, no water-quality data were available from the FDEP study. Duplicate point samples, however, were collected from the vent at Juniper Springs on April 29, 1996, by the SJRWMD. Nitrate-nitrogen concentrations for those duplicate samples were 0.07 and $0.08 \mathrm{mg} / \mathrm{L}$, below the $0.2 \mathrm{mg} / \mathrm{L}$ threshold established for that study (Toth, 1999). The studies by FDEP and SJRWMD did not include any of the additional areas evaluated in our study.

Macrophyte samples were collected from an abnormally dense stand of eelgrass, a native rooted submersed macrophyte. The elongated leaf blades of the eelgrass were covered with thick epiphytic invasive filamentous algae, similar to those at the ONF Salt Spring Marina (Figure 2E). The typical appearance of eelgrass is shown in the leaf tip in the foreground of Figure 2E, with the algae removed. Duckweed, the invasive floating-leaf aquatic macrophyte near the base of the eelgrass leaf tip (foreground), approximates the size of the date on the penny.

Ultimately those invasive epiphytes will prevent light from reaching the leaf blades of the native macrophytes and result in the demise of the eelgrass community, as has occurred at Alexander Springs. The source of anthropogenic nitrogen at our Juniper Springs study area appears to be consistent with the source at Alexander Springs, via the localized, surficial groundwater flow system. The low concentrations of nitrate-nitrogen from the spring vent sampled by Toth (1999) and the endpoint values for septic tank effluent from his studies conducted in the vicinity of our study areas provide additional support for the conclusion about the sources of nitrogen contamination at the ONF study areas and the assumption that fractionation has not occurred in our macrophyte samples.

\section{Springs on State Lands}

\section{Orange Grove and Peacock Springs}

The $\delta^{15} \mathrm{~N}$ results from Orange Grove and Peacock Springs in Figure 5 also represent the combined data from the species present at each of those two relatively small 
study areas. The range in $\delta^{15} \mathrm{~N}$ values at Orange Grove Springs, from $+5.2 \%$ for stonewort (or musk-grass, an un-rooted, submersed aquatic) to $+8.8 \%$ for yellow cowlily (a rooted emergent), accounts for the largest standard deviation (SD) observed at all of the springs study areas. Those differences may be related to differences in growth form of the two taxa or may represent two different sources of nitrogen entering Orange Grove Spring.

A $\delta^{15} \mathrm{~N}$ value in the range exhibited by the un-rooted macroalga stonewort is indicative of an organic nitrogen source such as animal manure. Stonewort is recognized as an indicator of deep-aquifer discharge (Rosenberry et al., 2000; Bacchus, unpublished data for Florida), and preferentially takes up minerals from the spring waters. Those characteristics suggest potential uptake of nutrients from those discharges. The abnormally dense mats of stonewort and yellow cow-lily, combined with the obviously unsuitable conditions for swimming (microalgal bloom covering the surface of the spring and lack of flow), the lack of a septic tank and drainfield at this study area, and the undeveloped watershed immediately surrounding the spring, all suggest that the source of nitrogen at this spring is animal waste transported to the spring via the Floridan aquifer.

No vascular macrophytes were available for sampling at Peacock Spring. The un-rooted filamentous macroalgae collected from the Peacock Spring study area had the lowest $\delta^{15} \mathrm{~N}$ signature of the springs that were evaluated in our study (Figure 5). That $\delta^{15} \mathrm{~N}$ signature was comparable to the signature $(+4.7 \%$ of macroalgae from an inshore site (Avenue J) at Big Pine Key, in the Lower Florida Keys. That area has direct exposure to sewage discharges and values were within the range reported for macroalgae growing on sewage nitrogen (Lapointe et al., 2004).

A relatively controlled field study in California reported a $\delta^{15} \mathrm{~N}$ signature for inorganic fertilizer in groundwater samples similar to our $\delta^{15} \mathrm{~N}$ value for Peacock Springs (Fogg et al., 1998). The $\delta^{15} \mathrm{~N}$ value of nitrate in fertilizers, however, "is generally less than $+3 \%$ o" (Toth, 1999, p. 41), which is lower than the mean and standard deviation for the Peacock Springs results.

Unlike the U.S. Forest Service recreation areas at Alexander and Juniper Springs, the area immediately surrounding Orange Grove and Peacock Springs has not been sodded or otherwise developed with lawns, septic tanks or drainfields. Therefore, the $\delta^{15} \mathrm{~N}$ results for the macroalgal samples from Peacock Springs appear to be indicative of either animal waste or sewage effluent entering the spring from the springshed via regional flow, rather than from the surficial aquifer.

\section{Wakulla Springs}

The FDEP springs report included results from a single point-sample collected on September 27, 2001. Unfiltered
$\mathrm{NO}_{3}+\mathrm{NO}_{2}$ and $\mathrm{NH}_{3}+\mathrm{NH}_{4}$ concentrations from that sample were 0.99 and $0.01 \mathrm{mg} / \mathrm{L}$, respectively, whereas filtered concentrations were $0.96 \mathrm{mg} / \mathrm{L}$ and $0.01 \mathrm{mg} / \mathrm{L}$, respectively. The unfiltered total-nitrogen value was estimated and the values for total ammonia represented the method detection limits. Bacterial analyses of water samples collected from the Wakulla Springs vent during that FDEP study were the same as those conducted for Alexander Springs, again implying that sewage effluent was not a factor in elevated concentrations of nitrogen. Those samples, however, also exceeded the holding time limit (Scott et al., 2002). Despite these shortcomings, the FDEP results are indicative of anthropogenic nitrogen discharging from the regional aquifer.

Dye-tracer studies have confirmed rapid groundwater flow through the regional aquifer system from the vicinity of the municipal effluent sprayfield in Leon County to Wakulla Springs (Davies et al., 2004; Hazlett et al., 2004; and Kincaid et al., 2004). Unlike the springshed for Orange Grove and Peacock Springs, large-scale industrial animal feedlot operations are not located in the Wakulla Springs springshed or watershed.

The results of the dye-tracer studies combined with elevated nitrogen levels in water samples from the Wakulla Springs vents suggest that the springshed is the source of the nitrogen taken up by the dense invasive macrophytes at the Wakulla Springs study area. The transport of nitrogen-contaminated ground water is presumed to occur as conduit flow through the Floridan aquifer (illustrated in Figure 3), with the probable source being sewage effluent from the municipal sprayfield in Leon County.

The $\delta^{15} \mathrm{~N}$ signature of the invasive macrophytes from Wakulla Springs (provided in Figure 5) is comparable to the lowest $\delta^{15} \mathrm{~N}$ values $(\sim+6$ to $7 \%$ measured in October and December macroalgal samples from the coastal east-central Florida study by Barile (2004). Those values were attributed to nearby sewage nitrogen sources.

\section{Lake Placid}

\section{Species Comparisons}

A comparison of the same macrophyte species at each of the Lake Placid sites and all study areas could have provided information regarding potential species-specific responses. Unfortunately, a comprehensive comparison of species from all study areas, or even all sites within the Lake Placid study area, was not possible because species composition varied among study areas and among sites within the same study area. Observations during site inspections and sample collection suggested that vegetative phase shifts had occurred, as described in the section below. Those observations and knowledge of surrounding land use supported the conclusion that nutrient 
contamination from different sources and of different magnitudes resulted in different species compositions.

Elderberry (a native rooted species) was one species present at eight locations in the southern end of Lake Placid where the industrial dairy operation is located. The samples of this species, collected on the same date within relatively close proximity, but exposed to different conditions, facilitated a comparison of a single species. Only leaf samples were collected and analyzed, for reasons described above.

Samples from five of the elderberry collection locations adjacent to Sites 11, 14, 15, 16 and 17 (Figure 4) were considered as "controls", because the plants were rooted in an area at the sample site that was presumed not to be exposed to surface water or shallow ground water containing anthropogenic nitrogen from any of the sources identified at the Lake Placid study area. Samples from the remaining three sites were collected from plants rooted in areas downgradient of the industrial dairy operation (Figure 4, Sites 10, 12 and 13). No septic tanks were located in proximity to Sites 12 and 13 . Site 10 was located upgradient (southwest) of homes with septic tanks (Figure 4). Based on contour elevations from U.S. Geological Survey 7.5 minute topographic maps of the area, the approximate land-surface elevations for Sites 10, 11, 12, 13 and 15 (all downgradient from the dairy operation) were $\sim 37.5 \mathrm{~m}, \sim 38.7 \mathrm{~m}, \sim 40.5 \mathrm{~m}, \sim 41.8 \mathrm{~m}$ and $\sim 42.6 \mathrm{~m}(\sim 123 \mathrm{ft}, \sim 127 \mathrm{ft}, \sim 133 \mathrm{ft}, \sim 137 \mathrm{ft}$ and $\sim 140 \mathrm{ft})$, respectively.

A summary of the $\delta^{15} \mathrm{~N}$ analysis results for the comparison of elderberry is provided in Table 2. The mean for the samples identified as "controls" was $+1.8 \%$ $( \pm 0.6 \%$ oo $)$ whereas the mean for the samples presumed to be exposed to surficial aquifer water containing nutrients from the industrial dairy operation or possibly septic tank leachate was $+9.7 \%$ o $( \pm 2.3 \%$ o $)$. The $\delta^{15} \mathrm{~N}$ range of +1.0 to $2.5 \%$ for elderberry in the "control" group (Sites 11 , $14,15,16$ and 17) is presumed to represent natural fixed nitrogen in the soil. Fogg et al. (1998, p. 425) found that the "mean $\delta{ }^{15} \mathrm{~N}$ for the soil organic matter sites was about $+2.5 \%$ " which is similar to the "control sites" for the rooted emergent macrophytes evaluated at the south end of Lake Placid. The "fertilized" sites in their study had both higher $(\sim 3.5 \%)$ and lower $(\sim 1.5 \%)$ values than the soil organic matter values in their study. Therefore, it is possible that results from some of the "control" sites (e.g., Sites 16 and 17) may include input from an inorganic nitrogen fertilizer source, such as orange groves. In comparison, 21 samples of tropical macroalgal samples from relatively unpolluted coastal waters of southwestern Puerto Rico had a mean $\delta^{15} \mathrm{~N}$ of $+0.5 \%$ $( \pm 1.0 \%)$, indicative of nitrogen fixation as the source of nitrogen supporting their growth (Lapointe et al., 2004).

The $\delta^{15} \mathrm{~N}$ range for the remaining elderberry speciescomparison sites was +6.4 to $12.3 \%$. Bacteriological and
Table 2. Mean $\pm S D$ stable nitrogen isotope $\left(\delta^{15} N, N=2\right)$ values for the rooted native macrophyte Sambucus canadensis $L$. (elderberry) from control and nutrient-source sites associated with Lake Placid, Florida.

\begin{tabular}{|c|c|c|}
\hline Site $^{1}$ & Site Description ${ }^{1}$ & $\delta^{15} \mathrm{~N}$ \\
\hline \multicolumn{3}{|c|}{ Controls } \\
\hline 11 & control tributary channel, $\mathrm{W}$ branch & $+2.5^{2}$ \\
\hline 14 & swamp, SR $70 \mathrm{~W}$ of dairy & $+1.6 \pm 0.4$ \\
\hline 15 & roadside ditch, SR $70 \mathrm{E}$ of dairy & $+1.2 \pm 0.2$ \\
\hline 16 & roadside ditch, SR 70, S Lake Annie & $+2.2 \pm 0.2$ \\
\hline \multirow[t]{2}{*}{17} & roadside ditch, SR 17, N Lake Annie & $+1.9 \pm 0.8$ \\
\hline & Mean & $+1.8 \pm 0.6$ \\
\hline \multicolumn{3}{|c|}{ Nutrient-Source } \\
\hline 10 & ditch, Placid View Drive & $+12.0 \pm 0.3$ \\
\hline 12 & dairy waste tributary, downstream/N & $+9.6 \pm 2.5$ \\
\hline \multirow[t]{2}{*}{13} & dairy waste tributary, SR 70 & $+7.6 \pm 1.2$ \\
\hline & Mean & $+9.7 \pm 2.3$ \\
\hline
\end{tabular}

$\mathrm{SR}=$ State Road

${ }^{1}$ As shown in Figure 4.

${ }^{2}$ Sole duplicate with negative value discarded as outlier/error.

nutrient results from the Highlands Soil and Water Conservation District's water samples (referenced above), which were collected from the same tributary locations as sites 12 and 13 in our study, supported the conclusion that those tributary locations contained discharge from the dairy-waste lagoon south of Highway 70 . The results of those water samples, combined with the absence of septic tanks in that vicinity, support the conclusion that dairy waste is the source of the elevated $\delta^{15} \mathrm{~N}$ signature in elderberry leaves collected from Lake Placid Sites 12 and 13 in our study.

The increase in mean $\delta^{15} \mathrm{~N}$ value from $+7.6 \%$ at Site 13 to $+9.6 \%$ downgradient at Site 12 approximates the $2.7 \%$ increase attributed to 10 percent denitrification of $\mathrm{NO}_{3}$ by organic soils under controlled laboratory conditions, described by Fogg et al. (1998). Our study areas at springs that appear to have shallow groundwater sources for nitrogen contamination (described above) lack significant organic soils between the apparent source of contaminant discharge to the surficial aquifer and the downgradient surface-water sample sites. Organic soils are associated with the extensive forested seepage wetland (swamp) at the southern end of Lake Placid, however, between the dairy and Lake Placid. Denitrification may be occurring in those organic soils as a plume of nutrient-laden ground water originating from the dairywaste lagoon flows laterally through the surficial aquifer toward Lake Placid. That scenario could account for the elevated mean $\delta^{15} \mathrm{~N}$ values of $+9.6 \%$ and $12.0 \%$ at Sites 12 and 10, respectively, in elderberry that was growing in the vicinity of the tributaries at those sites. A less likely scenario is that septic tank leachate from homes along the shore in the vicinity of Placid View Drive is flowing 


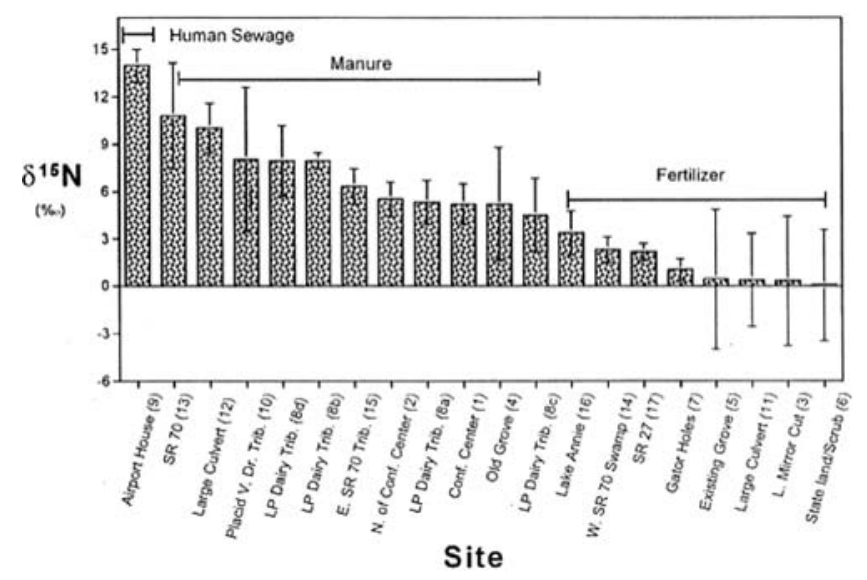

Figure 6. Stable nitrogen isotope values $\left(\delta^{15} \mathrm{~N}\right.$ mean $\left.\pm \mathrm{SD}\right)$ for macrophytes collected from sample sites associated with Lake Placid.

southwest, against the topographic gradient, to the shallow root zone of elderberry sampled at Site 10.

\section{Site Comparisons}

Results of $\delta^{15} \mathrm{~N}$ analysis from the numerous species collected from the 17 Lake Placid sample sites were clustered into three groups characteristic of the three categories of potential nitrogen discharge at this study area (Figure 6). The group with the highest $\delta^{15} \mathrm{~N}$ signature $(\sim+14 \%)$ was indicative of a mid-range value for septic tank leachate (Peterson and Fry, 1987). That group included macrophytes collected from a dense stand in the littoral zone downgradient of a home on the southwest shore of the lake (Figure 4, Site 9). No comparable growth of macrophytes was observed in the vicinity of any other homes on Lake Placid.

The group with the lowest $\delta^{15} \mathrm{~N}$ signature $(\sim+3 \%$ or less) included the range of nitrogen from inorganic fertilizer sources. As an example, Fogg et al. (1998, p. 423) evaluated a site that had been under agricultural production for more than 150 years and "augmented annually with up to $250 \mathrm{lb}$ N/acre from commercial fertilizers." The $\delta^{15} \mathrm{~N}$ results at that site for the "5 boreholes were consistent with each other, in addition to being nearly uniform with depth." The $\delta^{15} \mathrm{~N}$ values of soil water at that location ranged from a low of $-1.5 \%$ o to a high of $+4.3 \%$. That range also includes natural fixed nitrogen, however, as illustrated in the species comparison discussion above. The mean $\delta^{15} \mathrm{~N}$ value for natural fixed nitrogen at Lake Placid appears to be $+1.8 \% \pm 0.6$ (Table 2). Those data suggest that some of the sites included within the "fertilizer" group in Figure 6 (e.g., Site 7) may reflect natural fixed nitrogen. That group included plants collected from the Lake Placid littoral zone (Figure 4, Sites 3, 5, 6 and 7), in addition to tributaries/ditches (Figure 4, Sites 11, 14, 16, and 17).

The remaining Lake Placid sites exhibited a $\delta^{15} \mathrm{~N}$ signature attributed to organic nitrogen, presumably dairy waste (e.g., manure) from the industrial dairy feedlot operation upgradient of Lake Placid. That group included plants collected from the Lake Placid littoral zone (Figure 4, Sites 1, 2, 4, and 8a-d) and tributaries/ditches (Figure 4, Sites 10, 12, 13, and 15).

The surrounding land at Sites 2, 6, 7, 8, 10, 11, 12, 16 and 17 primarily was naturally vegetated, without homes or groves, or surface runoff from those land uses. Samples from Sites 11, 14, 16 and 17 may have received nitrogen from stormwater runoff. Samples from the tributary flowing north from Lake Annie (Site 16) and the associated downstream wetlands (Site 17) also may be receiving nitrogen from groves located $\sim 1 \mathrm{~km}(\sim 0.5$ mi) northeast, via lateral flow in the surficial aquifer.

Results of elderberry samples from sites listed in Table 2 are inconsistent with results provided for some of those sites shown in Figure 6. This is because Site 11 was the only species-comparison location where elderberry plants (Table 2) were growing in the surface water (e.g., tributary channel) with the remaining macrophytes evaluated and reported in Figure 6.

The isotopic signatures of the macrophytes from various sample collection sites shown in Figure 6 suggest that organic nitrogen from the dairy operation in the southern portion of the watershed is entering Lake Placid more than $3 \mathrm{~km}(\sim 2 \mathrm{mi})$ downgradient (north) and contributing to nitrogen contamination of the lake. Nitrogen from this dairy feedlot operation appears to be entering the lake via shallow groundwater discharge, as well as via the natural tributary that flows from the dairy into Lake Placid (Site 8a).

The conclusion described above is supported, in part, by the pattern of macrophyte growth in the southern portion of Lake Placid (Sites 8b-d), which is similar to growth patterns associated with groundwater seepage described by Rosenberry et al. (2000). This conclusion also is supported by the significant shallow groundwater seepage that was observed flowing out from under and through the berm constructed at the dairy waste lagoon and other areas along the northern perimeter of the property containing the dairy operation.

Additional support for the magnitude of contaminated discharge from the dairy operation was provided by water-quality analysis conducted by the Highlands County Lake Management Program. For example, on August 23, 2001, $\mathrm{NO}_{3}+\mathrm{NO}_{2}$ was $0.75 \mathrm{mg} / \mathrm{L}$ and total nitrogen was $3.48 \mathrm{mg} / \mathrm{L}$ in water samples collected at the mouth of the primary tributary receiving discharges from the dairy, in the vicinity of our Site 8a (Ford, 2002a). The $0.75 \mathrm{mg} / \mathrm{L}$ value for $\mathrm{NO}_{3}+\mathrm{NO}_{2}$ from Lake Placid, in the vicinity of the dairy, is comparable to the values for 
Wakulla Springs water samples collected from the spring vent (Scott et al., 2002) and attributed to groundwater input from the Leon County municipal sprayfield.

Nitrogen-contaminated discharges from the referenced dairy also could be responsible for the isotopic signatures of $\sim+6 \%$ at Sites 1, 2, and 4, in the littoral zone of the northern shore (Figure 4). The transport mechanism could be wind-driven surface discharges from the tributary in the vicinity of Site $8 \mathrm{a}$ or focused (discrete) subsurface discharges. The $\delta^{15} \mathrm{~N}$ signatures for samples from the dairy waste lagoon (Site 15) and the tributary mouth (Site 8a) are similar to the $\delta^{15} \mathrm{~N}$ means and standard deviations for Sites 1 and 2 along the north shore of Lake Placid (Figure 6). The greater standard deviation for samples from Site 4 may be the result of groundwater discharge of inorganic fertilizers applied before the orange grove operation at that location was abandoned.

These results, suggesting extensive contamination of Lake Placid from the industrial dairy operation, are consistent with results of water-quality samples collected by the Highlands Soil and Water Conservation District. No sampling was conducted or required by FDEP to determine the cause of the harmful algal blooms or the increasing abundance of invasive macrophytes in Lake Placid.

\section{Bulow Creek}

\section{Results and Land-Use During Sample Collection}

The more extensive data set for Lake Placid facilitates interpretation of $\delta^{15} \mathrm{~N}$ for invasive macrophytes collected in Bulow Creek. Results from Bulow Creek are included with results from the spring-run stream and springs study areas in Figure 5 and are within the range of both animal waste (manure) and human waste (sewage effluent). Those results represent the combined samples from the mouth of a small tributary $\sim 1.6 \mathrm{~km}(\sim 1 \mathrm{mi})$ north of the state historical site and from the opposite side of the Bulow Creek channel $\sim 1.6 \mathrm{~km}$ south of the state historical site. The mouth of the tributary is shown as a small protrusion from the western channel of Bulow Creek, north of the green area labeled "Bulow Creek State Park" on the Tomoka Marsh Aquatic Preserve map (provided at http://www.dep.state.fl.us/coastal/downloads/ maps/default.htm).

The most probable source of nitrogen in the northern sample subset is the cattle pasture in the flood plain west of Old Kings Road (County Road 4011 on the Tomoka Marsh Aquatic Preserve map). The $\delta^{15} \mathrm{~N}$ signature for that subset was comparable to the $\delta^{15} \mathrm{~N}$ value for the tributary discharging water to Lake Placid from the industrial dairy operation (Figure 5, Site 8a).

No other large-scale or concentrated animal feedlot operations are associated with the Bulow Creek portion of the watershed. That operation appeared to include fewer cows than the 320 cows reported by FDEP (FDEP Case No. FLA284611, Administrative Agreement, January 29, 2002) at the industrial dairy operation adjacent to the Lake Placid study area. The Bulow Creek cattle operation, however, was located closer to the water body. The transport of animal wastes to Bulow Creek from that source could be via shallow groundwater flow, with contaminant access increased by mine pits excavated into the surficial aquifer in the cattle pasture. Aquifer excavation has been shown to increase the threat of groundwater contamination and lateral groundwater flow (Zamora et al., 2003; Wilcox et al., 2004).

The southern sample subset at Bulow Creek was collected from the opposite side of the stream channel at an equal distance downstream of the state historical site and adjacent to a single-family residence situated $\sim 120 \mathrm{~m}$ ( $\sim 400 \mathrm{ft}$ ) east of the Bulow Creek stream channel. The house was constructed in the early 1980s. A dense marsh composed of native plant species occupies the littoral zone from the natural channel of Bulow Creek to the adjacent single-family residence. That sample subset was within the lower range of sewage effluent.

One possible scenario is that leachate from the septic tank drain field at that house flows through the littoral zone marsh, and that nitrogen loads recently exceeded the uptake capacity of the marsh plants and are discharging to the surface waters of Bulow Creek. A second, more likely scenario is that a discrete leachate plume is flowing through the surficial aquifer, beneath the root zones of those marsh plants, and recently began discharging beneath the surface of Bulow Creek at that sample collection site. The latter scenario is supported by the fact that septic tank leachate augments groundwater flow in a localized area of the surficial aquifer and could result in focused subsurface point-source discharges to Bulow Creek. Similar focused discharges appeared to be occurring along the southern shoreline of Alexander Springs, downgradient of the ONF drainfield. Comparable focused recharge was reported under natural depressional wetlands receiving wastewater in Texas, along with other preferential pathways, such as through desiccation cracks in the clay (Fryar et al., 2000). Analogous natural spring discharges have been observed along littoral zones in other ecosystems (Rosenberry et al., 2000).

No additional houses or STPs were located within $\sim 1 \mathrm{~km}(\sim 0.5 \mathrm{mi})$ of the sample locations on either side of Bulow Creek at the time of our study. The discrete mass of invasive macrophytes at both locations where these Bulow Creek subset samples were collected suggests that significant nitrogen sources were associated with those two locations, similar to the discrete plumes described by Fogg et al. (1998) and referenced above.

Other potential sources for the elevated $\delta^{15} \mathrm{~N}$ signa- 
tures at those locations in Bulow Creek occur in the watershed between the two locations for the Bulow Creek samples. Those potential sources include $\sim 30$ houses on the east side of Bulow Creek in Flagler County, although none are in proximity to the southern sample location. On the west side of the creek, a recreational vehicle (RV) park dating from the 1960s, with a mobile home park added in the 1980s, is located along the northern boundary of the state historic site. A mobile home park adjacent to the southern boundary of the state historical site was constructed in the late 1990s. The package STP for that mobile home park is located $\sim 1.2 \mathrm{~km}(\sim 0.8 \mathrm{mi})$ west of the Bulow Creek stream channel. The state historical site includes public bathrooms and a ranger residence that also may discharge sewage effluent to the surficial aquifer, ultimately flowing into Bulow Creek.

The spatial separation of the potential sources and the discrete clusters of invasive macrophytes at this study area were similar to those at the Lake Placid industrial dairy operation. Unlike the absence of other potential nitrogen sources from the watershed in the vicinity of the Lake Placid dairy operation, however, the watershed in the vicinity of the Bulow Creek study area includes numerous potentially large sources of human waste. Therefore, additional research is required to confirm that nutrients from the cattle operation are entering Bulow Creek via surficial groundwater discharge. Additional information also is needed to confirm sources and flowpaths for the sewage-effluent nutrient load to Bulow Creek.

\section{Permitted and Proposed Land-Use Changes}

Among our study areas, the Bulow Creek watershed has the most extensive permitted and proposed land-use changes. Since this study was conducted, the cattle operation is being replaced by a residential subdivision of $\sim 750$ homes proposed for the area surrounding the open pit. Permits have been issued to expand the mobile home park bordering the northern boundary of the state historical site, as well as for the construction of a 108unit subdivision directly across from the mobile home park that borders the state park on the north (SJRWMD Permit Number 4-036-87306-1). A second subdivision (reported as "200 acres") is proposed for 40 houses adjacent to this proposed 108-unit subdivision (unpublished SJRWMD permit document). Additional land on the west side of Bulow Creek is under the same ownership and subject to similar development. If any of these land-use changes occur, subsequent sample events may provide significantly different results than those reported in this study.

Unlike the lower reaches of Bulow Creek, where an expansive littoral zone marsh occurs and can buffer nutrient inputs to Bulow Creek, the area where high- density developments have been permitted or proposed lacks a similar buffering wetland. Individual septic tanks and wells were proposed for all of the houses in the highdensity developments. Based on the apparent potential for a single septic system on the east side of Bulow Creek to support the growth of invasive macrophytes occurring at the adjacent (downstream) sample collection site, significant eutrophication is predicted to occur throughout Bulow Creek and in downstream coastal waters if those developments proceed as permitted or proposed.

\section{Fractionation, Denitrification and Lateral Flow}

The assumption that the $\delta^{15} \mathrm{~N}$ values were not fractionated in plant material evaluated in this study is supported by the fact that the Toth (1999) endpoint values match the values in the macrophyte samples from our springs study sites. This assumption also is supported by the determination that fractionation in marine macrophyte samples is minimal (Barile, 2004). Isotopic fractionation can occur in water and soil samples collected for $\delta^{15} \mathrm{~N}$ analysis that are not properly preserved during the time between collection and analysis. Fogg and others (1998) conducted a long-term storage study on frozen soil cores to test the means of preserving samples recommended by the U.S. Environmental Protection Agency as the best preservation technique available, refrigeration of samples near freezing or below. Their study showed that "no significant changes occurred in either the $\mathrm{NO}_{3}$ concentration or $\delta^{15} \mathrm{~N}$ during the 56-week interval" (Fogg et al., 1998, p. 420). The macrophyte samples in our study were transported on ice, then dried and analyzed, or dried and frozen until analysis if analysis was delayed. Therefore, the assumption that fractionation in our macrophyte samples was insignificant should be valid.

Denitrification can result in an increase in $\delta^{15} \mathrm{~N}$ values. Ground water from five irrigation wells sampled by Fogg and others (1998, p. 424), however, revealed that "significant denitrification is occurring only in localized pockets of the subsurface." The results from those irrigation wells were consistent with results from the vadose zone for fertilizer signatures in their study.

Fogg and others (1998) also discussed scenarios other than denitrification that could lead to increasing $\delta^{15} \mathrm{~N}$ with depth. One scenario was "transient transport in which elevated $\delta^{15} \mathrm{~N}$ deeper in the profile is due to an older source that has since been replaced at the surface by a source having lower $\delta^{15} \mathrm{~N}$." Another scenario they described was "lateral flow contributing higher $\delta^{15} \mathrm{~N}$ from off site." That scenario was determined to be plausible "if the off-site source is fairly close to the profile or if perched conditions exist" (Fogg et al., 1998, p. 421). Perched conditions could exist for the surficial aquifers in our study. Denitrification is not considered to be a factor in our sites characterized by lateral flow 
through the sandy surficial aquifer prior to discharge into surface waters. Exceptions include cases in which the ground water may pass through extensive wetland areas with organic soils, such as in the southern end of Lake Placid.

\section{Vegetative Phase Shifts}

The sites evaluated in this study are typical of naturally oligotrophic ecosystems in the southeastern Coastal Plain. These ecosystems are characterized by the occurrence of few macrophyte species that grow in sparse stands when present, primarily as the result of low nutrient concentrations in both the water column and substrate. Examples of un-rooted macrophytes adapted to grow under such naturally nutrient-limited conditions include carnivorous species of Utricularia (bladderwort) that capture and digest tiny organisms from the water column as a source of nitrogen (Bosserman, 1979; Godfrey and Wooten, 1981). Eelgrass is an example of a rooted macrophyte adapted to these naturally nutrientlimited conditions. All are vascular macrophytes.

Vegetative phase shifts that are a consequence of anthropogenic nutrients can occur as either an abnormal abundance of macrophytes characteristic of these naturally nutrient-limited conditions, or as the occurrence of invasive macrophytes. Conversely, the macrophytes involved in these shifts can be used as indicator species for anthropogenic nutrient contamination. In a study that accounted for aerial deposition of nutrients, Stinner (1983) found that duckweed did not occur naturally in those oligotrophic aquatic ecosystems of the southeastern Coastal Plain. The predominant species of duckweed that occurred in the elevated nutrient plots in that study was Lemna valdiviana, the same invasive species that was predominant in our study areas. Biomass of submersed macrophytes (Utricularia and Cabomba) has been shown to increase significantly when exposed to fertilization, compared to reference aquatic ecosystems. Invasive submersed macrophytes such as Cabomba have been shown to exhibit directional responses to anthropogenic sources of nutrients, establishing sufficient biomass within two years of nutrient additions to result in an "overwhelming proportion" compared to naturallyoccurring Utricularia. As a rooted submersed macrophyte, Cabomba is able to acquire nutrients from both the water column and the sediments (Sculthorpe, 1967).

Both chronic and acute anthropogenic nutrient discharges to naturally nutrient-limited ecosystems, including advanced wastewater treatment discharges, have resulted in vegetative phase shifts. Point-source surface discharges of sewage effluent (Dierberg and Brezonik, 1978) and sewage sludge (Valiela et al., 1975) to wetlands (also considered aquatic sites) resulted in such shifts, including species replacement compared to control sites. Similar vegetative phase shifts should be expected to occur from subsurface point-source and non-pointsource discharges of sewage effluent to aquatic sites in our study areas, particularly Alexander, Juniper, and Wakulla Springs.

The stages of vegetative phase shifts appear to be, from initial to final stage: (1) abnormal abundance of native vascular macrophytes adapted to naturally nutrient-limited conditions; (2) occurrence of invasive non-vascular macrophytes suspended in the water column, or as epiphytes covering desirable native macrophytes (Figure 2E) and typically bare submerged substrate (Figure $2 \mathrm{~B}$ and 2C), particularly when nutrient discharges occur as subsurface discharges; (3) occurrence of invasive macrophytes on the water surface or in the water column (Figure $2 \mathrm{~A}$ and $2 \mathrm{D}$ ), primarily as floating or submersed growth forms, and rooted emergents; and (4) coverage of $\sim 50$ to 100 percent of the water surface, the water column, the native macrophytes, and/or the benthic substrate by invasive vascular and non-vascular macrophytes.

This series of vegetative phase shifts can be used to describe the stage of the nutrient contamination continuum each study area represented at the time of the evaluation. Juniper and Orange Grove Springs were in transition between Stages 1 and 2. Peacock Springs was in transition between Stages 2 and 3. Bulow Creek would be classified as Stage 3. The main Alexander Springs swimming area (south shore, Figure 2C) would be classified as Stage 2, but the invasive macrophytes (primarily suspended on the bottom and in the water column) probably are being displaced by swimmers and waders. Figure $2 \mathrm{~B}$ illustrates the less popular southern portion of the swimming area, whereas Figure 2D is characteristic of conditions in the unused, northern portion of the swimming area and the upper reaches of Alexander Spring-Run, which would be classified as Stage 4. Wakulla Springs (Figure 2A) also meets the criteria of Stage 4, despite attempts to control the invasive macrophytes by herbicides and by mechanical and manual removal. Conditions of the Lake Placid sites downslope of the industrial dairy operation also would be classified as Stage 4. Conditions at the ONF Wildcat Lake Recreation Area public access (Figure 2F), adjacent to the self contained waterless public toilets that contribute no discharge to the lake, are representative of pre-contamination conditions at the study areas.

\section{SUMMARY AND CONCLUSIONS}

Stable nitrogen isotope $\left(\delta^{15} \mathrm{~N}\right)$ analysis of macrophytes represents time-integrated data capable of providing inferences about adverse environmental impacts and the source(s) of nitrogen contaminants, in addition to complementing time-specific water-quality data. Using $\delta^{15} \mathrm{~N}$ analysis, we have demonstrated that uptake of 
anthropogenic nitrogen has occurred in invasive alien and nuisance native macrophytes exhibiting harmful growth in Florida's freshwater ecosystems. We suggest that $\delta^{15} \mathrm{~N}$ analysis of freshwater macrophytes, combined with other information (e.g., watershed and springshed land-use information, groundwater flow characteristics, and, to a lesser extent, hydraulic-head maps and water-quality analyses based on discrete data) can provide evidence of nitrogen contamination sources and groundwater flowpaths in other karst aquifer systems.

Study areas were selected in locations of Florida where special protection of surface waters is required by law. These included aquatic ecosystems within and adjacent to the ONF, and state lands, including Aquatic Preserves and Outstanding Florida Waters, where pre-invasion conditions of those ecosystems were known. The natural community types evaluated in this study included springs (Alexander, Juniper, Orange Grove, Peacock and Wakulla), a spring-run stream (Alexander Spring-Run), a blackwater stream (Bulow Creek), and a sinkhole lake (Lake Placid). Invasive macrophytes that were evaluated in this study included those designated as Category I and II species by the Florida Exotic Pest Plant Council, and examples of both invasive alien and nuisance native species.

Stable nitrogen isotope analysis of macrophytes from naturally-oligotrophic freshwater aquatic ecosystems in subregions of the Floridan aquifer system confirmed contamination from uptake of anthropogenic nitrogen (manure, sewage effluent and/or inorganic fertilizer). Those results were augmented with knowledge of historic (pre-invasion) conditions of ecosystem integrity; characteristics of the selected natural communities and associated aquifer system; potential sources of anthropogenic bioavailable nitrogen in the watershed and springshed surrounding each study area; and other available data. Based on the methods used in our study and values from anthropogenic nitrogen sources in water samples that matched macrophyte values in our study, fractionation above source values was presumed to be negligible. The results of this study indicate that the federal and state designations have failed to protect the natural ecological integrity of the aquatic systems evaluated in this project.

Macrophyte samples from Alexander Springs and Spring-Run had $\delta^{15} \mathrm{~N}$ signatures suggesting contamination with human sewage effluent. A previous study by FDEP concluded that Floridan-aquifer discharge did not contribute significant amounts of nutrients to Alexander Springs. Because of the National Forest designation, the watershed immediately surrounding the spring is undeveloped, except for the commercial concessionaire facilities associated with the U.S. Forest Service's Alexander Springs Recreation Area. The other ONF spring study area, Juniper Springs, exhibited early vegetative phase shift conditions similar to those at the
ONF Salt Spring Marina, where the rooted native eelgrass is abnormally dense, but the elongated leaf blades are covered with epiphytic macrophytes. The source of anthropogenic nitrogen at the Juniper Springs study area also appears to be lateral flow through the sandy surficial aquifer.

Among springs on state lands evaluated in this study, the watershed surrounding Orange Grove and Peacock Springs exhibited the least disturbance, with no on-site sewage effluent disposal or developed recreation facilities comparable to those at the Alexander and Juniper Springs study areas. Macrophytes from Orange Grove Spring had $\delta^{15} \mathrm{~N}$ signatures indicative of organic nitrogen from animal waste (manure) and possibly from human sources transported to the spring via the Floridan aquifer. The invasive, filamentous macrophytic algae analyzed from Peacock Spring had a $\delta^{15} \mathrm{~N}$ signature comparable to that of macroalgae from an inshore site in the Lower Florida Keys with direct exposure to sewage discharges, and within the range reported for macroalgae growing on sewage nitrogen. Although the source of the nitrogen at Peacock Springs is not known, the nitrogen appears to be discharging from the Floridan aquifer.

The invasive macrophytes sampled at Wakulla Springs had a $\delta^{15} \mathrm{~N}$ signature indicative of treated sewage effluent. This is consistent with dye-tracer studies showing rapid groundwater flow through the regional aquifer system from the vicinity of the municipal effluent sprayfield in Leon County and with elevated nitrogen levels in water samples from the Wakulla Springs vents.

Results from discrete clusters of invasive macrophytes in Bulow Creek suggested nitrogen discharges within the range of both animal waste and sewage effluent. A potential source for nitrogen from animal waste was the cattle operation and open mine pit located in the flood plain. The cattle operation was located a comparable distance from the west channel of Bulow Creek to the industrial dairy operation's distance south of Lake Placid. The other discrete cluster of macrophytes evaluated from Bulow Creek was associated with a single-family residence. No additional houses or STPs were located near those discrete clusters of invasive macrophytes. Other potential sources of sewage effluent contamination to adjacent portions of Bulow Creek include the state historical site and the associated mobile home and RV parks. Additional single-family residences also may contribute to elevated nitrogen concentrations in Bulow Creek. Shallow groundwater flow, with discrete subsurface discharge, is the most probable transport mechanism for nitrogen in invasive Bulow Creek macrophytes.

Land use in the watershed immediately surrounding Lake Placid, a natural sinkhole lake, was the most varied of the study areas. That land use included an industrial dairy-waste lagoon and associated feedlot operation 
(CAFO), single-family residences with septic tanks, and active and abandoned orange groves. These varied uses required a more extensive network of sample collection sites. The primary source of anthropogenic nitrogen at the Lake Placid site appeared to be localized flow of animal waste from the existing dairy operation waste lagoon.

In conclusion, results from this study indicated that uptake of anthropogenic nitrogen has occurred in invasive alien and nuisance native macrophytes in the four freshwater ecosystem types evaluated and was sufficient to support dense growth of invasive macrophytes at all of the "protected" areas that were evaluated. The source of the anthropogenic nitrogen in invasive macrophytes from Alexander and Juniper Springs, and Alexander Spring-Run in the Ocala National Forest's Recreation Areas appears to include underground discharge of sewage effluent and other wastes via the shallow surficial aquifer. The primary source of nitrogen contamination at Wakulla Springs appears to be sewage effluent from the Leon County municipal sprayfield, transported by karst conduits through the Florida aquifer system. For the remaining springs evaluated in our study, nitrogen from unidentified sources appears to be discharging from the Floridan aquifer. At Lake Placid, a dairy-waste lagoon contributed nitrogen via the sandy, surficial aquifer as well as via a tributary stream flowing through state lands. The Bulow Creek study area appears to be receiving contamination from both cattle and septic tank leachate, at least in part as localized surficial groundwater discharge. Additional research is needed to identify specific sources at study areas where multiple potential sources occur (e.g., Orange Grove and Peacock Springs). We suggest that $\delta^{15} \mathrm{~N}$ analysis of freshwater macrophytes, combined with basic knowledge of watershed and springshed land use and aquifer characteristics, can provide evidence of nitrogen contamination sources and groundwater flowpaths.

\section{ACKNOWLEDGMENTS}

The quality of the manuscript was improved significantly by the comments of an anonymous reviewer, J. Humphrey, and the editors. Collection of macrophyte samples from Bulow Creek and Lake Placid was facilitated by boats provided by N. Giambolvo and G. Gramling, respectively, with additional field assistance provided by G. Duggins, E. Gissendanner, T. Warnke, and D. White. Funding for the laboratory analysis of samples was provided, in part, by E. Gissendanner, the Flagler Regional Chapter of Floridians for Environmental Accountability and Reform, and Wetlands Alert. Permission to use images of the mapped submerged cave systems in the Floridan aquifer was provided by HazlettKincaid, Inc. The images in Figure 2A and Figure 2E were taken by $\mathrm{T}$. Warnke.

\section{REFERENCES}

Anderson, D. M.; Gilbert, P. M.; And Burkholder, J. A., 2002, Harmful algal blooms and eutrophication: Nutrient sources, composition, and consequences: Estuaries, Vol. 25, No. 46, pp. 704-726.

Ashrenas, L. R.; Johnson, S. L.; Gregory, S. V.; TANK, J. L.; AND WollheIM, W. M., 2004, A stable isotope tracer study of nitrogen uptake and transformation in an old-growth forest stream: Ecology, Vol. 85, No. 6, pp. 1725-1739.

BACchus, S. T., 2000, Predicting nearshore environmental impacts from onshore anthropogenic perturbations of ground water in the southeastern Coastal Plain, USA. In Institution of Engineers (Editors), Interactive Hydrology: 3rd International Hydrology and Water Resources Symposium, Vol. 2: Institution of Engineers, Perth, Western Australia, pp. 609-614.

Bacchus, S. T., 2001, Knowledge of groundwater responses-A critical factor in saving Florida's threatened and endangered species. Part I: Marine ecological disturbances: Endangered Species Update, Vol. 18, No. 3, pp. 79-90.

Bacchus, S. T., 2002, The 'ostrich' component of the multiple stressor model: Undermining Florida. In Porter, J. W. and Porter, K. G. (Editors), Everglades, Florida Bay, and Coral Reefs of the Florida Keys: An Ecosystem Sourcebook: CRC Press, Boca Raton, FL pp. 669-740.

BARILE, P. J., 2004, Evidence of anthropogenic nitrogen enrichment of the littoral waters of east central Florida: Journal Coastal Research, Vol. 20, No. 4, pp. 1237-1245.

Battaglin, W. A.; Kendall, C.; Chang, C. C. Y.; Silva, S. R.; and CAmpbell, D. H., 2001, Chemical and isotopic evidence of nitrogen transformation in the Mississippi River, 1997-98: Hydrological Processes, Vol. 15, No. 7, pp. 1285-1300.

Bosserman, R. W., 1979, The hierarchical integrity of Utriculariaperiphyton microecosystems. Ph.D. Dissertation, University of Georgia, Athens, GA, 266 p.

Burns, D. A. And Kendall, C., 2002, Analysis of delta N-15 and delta $\mathrm{O}-18$ to differentiate $\mathrm{NO}_{3}^{-}$sources in runoff at two watersheds in the Catskill Mountains of New York: Water Resources Research, Vol. 38, No. 5, Art. No. 1051.

Chang, C. C. Y.; Kendall, C.; Silva, S. R.; Battaglin, W. A.; and CAmpbell, D. H., 2002, Nitrate stable isotopes: tools for determining nitrate sources among different land uses in the Mississippi River Basin: Canadian Journal Fisheries Aquatic Sciences, Vol. 59, No. 12, pp. 1874-1885.

Cloern, J. E.; CAnuel, E. A.; AND Harris, D., 2002, Stable carbon and nitrogen isotope composition of aquatic and terrestrial plants of the San Francisco Bay estuarine system: Limnology Oceanography, Vol. 47, No. 3, pp. 713-729.

Davies, G. J.; Kincaid, T. R.; Hazlett, T. J.; Loper, D.; Dehan, R.; AND McKinlay, C., 2004, Why do quantitative groundwater tracing? Geological Society America Abstracts Programs, Vol. 36, No. 5, p. 134.

Davis, S. M., 1994, Phosphorus inputs and vegetation sensitivity in the Everglades. In Davis, S. M. and Ogden, J. C. (Editors), Everglades, the Ecosystem and its Restoration: St. Lucie Press, Delray, FL, pp. 178-270.

DeBruyn, A. M. H. And Rasmussen, J. B., 2002, Quantifying assimilation of sewage-derived organic matter by riverine benthos: Ecological Applications, Vol. 12, No. 2, pp. 511-520. 
Dierberg, F. AND BrezoniK, P. L., 1978, The effect of secondary sewage effluent on the surface water and ground water quality of cypress domes. In Odum, H. T. and Ewel, K. C. (Editors), Cypress Wetlands for Water Management, Recycling and Conservation: Fourth Annual Report to National Science Foundation (RANN) and the Rockefeller Foundation, Center for Wetlands, University of Florida, Gainesville, FL, Report PB282-159, National Technical Information Service, Springfield, VA, pp. 178-270.

Fleming, L. E.; Rivero, C.; Burns, J.; Williams, C.; Bean, J. A.; Shea, K. A.; And Stinn, J., 2002, Blue-green algal (cyanobacterial) toxins, surface drinking water, and liver cancer in Florida: Harmful Algae, Vol. 1, pp. 157-168.

Florida Department of Environmental Protection, 2000, Florida's Springs: Strategies for Protection and Restoration: Prepared by the Florida Springs Task Force, Tallahassee, FL, 57 p.

Florida Department of Natural Resources, 1990, Tomoka Marsh Aquatic Preserve Management Plan: Florida Department of Natural Resources, Tallahassee, FL, 132 p.

Florida Natural Areas Inventory and Florida Department of Natural Resources, 1990, Guide to the Natural Communities of Florida: Florida Department of Natural Resources, Tallahassee, FL, $111 \mathrm{p}$.

Florida Natural Areas Inventory, 2004, Report on the Rare Plant and Animal Species and Rare Wetland Communities Occurring Adjacent to Priority Springs and Spring-Runs in the SJRWMD: Special Publication SJ2004-SP39, St. Johns River Water Management District, Palatka, FL, 53 p.

Fogg, G. E.; Rolston, D. E.; Decker, D. L.; Louie, D. T.; And GRISMER, M. E., 1998, Spatial variation in nitrogen isotope values beneath nitrate contamination sources: Ground Water, Vol. 36, No. 3, pp. 418-426.

Ford, C., 2001, unpublished report, Highlands Soil and Water Conservation District, Sebring, FL, August 28.

Ford, C., 2002a, unpublished report, Highlands County Lake Management Program, January 16.

Ford, C., 2002b, unpublished report, Highlands Soil and Water Conservation District, Sebring, FL, January 16.

Fryar, A. E.; Macko, S. A.; Mullican III, W. F.; Romanak, K. D.; AND BenNETT, P. C., 2000, Nitrate reduction during ground-water recharge, Southern High Plains, Texas: Journal Contaminant Hydrology, Vol. 40, pp. 335-363.

Godfrey, R. K. AND Wooten, J. W., 1979, Aquatic and Wetland Plants of Southeastern United States: Monocotyledons: The University of Georgia Press, Athens, GA, 712 p.

Godfrey, R. K. And Wooten, J. W., 1981, Aquatic and Wetland Plants of Southeastern United States: Dicotyledons: The University of Georgia Press, Athens, GA, 933 p.

Handley, L. L. And Raven, J. A., 1992, The use of natural abundance of nitrogen isotopes in plant physiology and ecology: Plant Cell Environment, Vol. 15, No. 9, pp. 965-985.

Hazlett, T. J.; Kincaid, T.; Loper, D.; Davies, G. J.; Dehan, R.; AND McKinlay, C., 2004, Realistic numerical modeling of groundwater flow based on quantitative site characterization in the Woodville Karst Plain of North Florida: Geological Society America Abstracts with Programs, Vol. 36, No. 5, p. 31

Heaton, T. H. E., 1986, Isotopic studies of nitrogen pollution in the hydrosphere and atmosphere-a review. Chemical Geology, Vol. 59, pp. 87-102.

Jones, G. W.; Upchurch, S. B.; And Champion, K. M., 1996. Origin of Nitrate in Ground Water Discharging from Rainbow Springs: Southwest Florida Water Management District, Brooksville, FL, $172 \mathrm{p}$

Jones, G. W.; Upchurch, S. B.; AND Champion, K. M., 1997, Water Quality and Hydrology of the Homosassa, Weeki Wachee, and
Aripeka Spring Complexes, Citrus and Hernando Counties, Florida, Origin Increasing Nitrate Concentrations: Southwest Florida Water Management District, Brooksville, FL, 175 p.

KARR, J. R., 1990, Bioassessment and non-point source pollution: an overview. In Second National Symposium on Water Quality Assessment, EPA Office of Water, Washington, DC, pp. 4-1-4-18.

Katz, B. G; Hornsby, H.D; BohlKe, J. F.; and Mokray, M. F., 1999, Sources and Chronology of Nitrate Contamination in Spring Waters, Suwannee River Basin, Florida: U.S. Geological Survey Water-Resources Investigations Report, 99-4252, 59 p.

Kendall, C.; Silva, S. R.; and Kelly, V. J., 2001, Carbon and nitrogen isotopic compositions of particulate organic matter in four large river systems across the United States: Hydrological Processes, Vol. 15, No. 7, pp. 1301-1346.

Kincaid, T. R.; Davies, G. J.; Hazlett, T. J., Loper, D.; Dehan, R. AND McKinlay, C., 2004, Groundbreaking characterization of the karstified Floridan aquifer in the Woodville Karst Plain of North Florida: Geological Society America Abstracts Programs, Vol. 36, No. 5, p. 31.

Krause, R. E. AND RandolPh, R. B., 1989, Hydrology of the Floridan Aquifer System in Southeast Georgia and Adjacent Parts of Florida and South Carolina: U.S. Geological Survey Professional Paper 1403-D, 65 pp.

LaJtha, K. AND Michener, H. H. (Editors), 1994, Methods in Ecology: Stable Isotopes in Ecology and Environmental Science: Blackwell Scientific Publications, Oxford, U.K., 316 p.

Lapointe, B. E.; Barile, P. J.; And Matzie, W. R., 2004, Anthropogenic nutrient enrichment of seagrass and coral reef communities in the Lower Florida Keys: Discrimination of local versus regional nitrogen sources: Journal Experimental Marine Biology Ecology, Vol. 308, pp. 23-58.

Livingston, R. J., 2005, Restoration of Aquatic Systems, Marine Series Vol. 9: CRC Press, Boca Raton, FL, 296 p.

Miller, J. A., 1986, Hydrogeologic Framework of the Floridan Aquifer System in Florida and in Parts of Georgia, Alabama, and South Carolina: U.S. Geological Survey Professional Paper 1403-B, 91 p.

National Research Council, 1992, Restoration of Aquatic Ecosystems; Science, Technology and Public Policy: National Academy Press, Washington, DC, $378 \mathrm{p}$.

National Research Council, 2000, Clean Coastal Waters: Understanding and Reducing the Effects of Nutrient Pollution: National Academy Press, Washington, DC, 405 p.

Pardo, L. H.; Kendall, C.; Pett-Ridge, J.; and Chang, C. C. Y., 2004, Evaluating the source of streamwater nitrate using $\delta^{15} \mathrm{~N}$ and $\delta^{18} \mathrm{O}$ in nitrate in two watersheds in New Hampshire, USA: Hydrological Processes, Vol. 18, No. 14, pp. 2699-2712.

Peterson, B. J. AND Fry, B., 1987, Stable isotopes in ecosystem studies: Annual Review Ecology Systematics, Vol. 18, pp. 293-320.

Phlips, E. J.; Frost, J.; Yilmaz, M.; Stiegerwalt, N.; And Cichra, M., 2005, Factors Controlling the Abundance and Composition of Blue-Green Algae in Lake Griffin: Special Publication SJ2005-SP4, St. Johns River Water Management District, Palatka, FL, 108 p.

Rosenau, J. C.; Faulkner, G. L.; Hendry, C. W., JR.; and Hull, R. W., 1977, Springs of Florida: Bureau of Geology Bulletin No. 31, Florida Department of Natural Resources, $461 \mathrm{p}$.

Rosenberry, D. O.; Striegl, R. G.; And Hudson, D. C., 2000, Plants as indicators of focused ground water discharge to a northern Minnesota lake: Ground Water, Vol. 38, No. 2, pp. 296-303.

Ross, J. P., 2000, Effect of Toxic Algae on Alligators and Alligator Egg Development: Technical Research Report 6, Project No. FL 03, Water Resources Research Center, U.S. Geological Survey-University of Florida, Florida Museum of Natural 
History, Gainesville, FL, 15 p. Electronic document, available at http://users.ce.ufl.edu/ wrrc/ross1.pdf

Scott, T. M.; Means, G. H.; Means, R. C.; and Meegan, R. P., 2002, First Magnitude Springs of Florida: Florida Geological Survey Open File Report No. 85, 138 p.

Sculthorpe, C. D., 1967, The Biology of Aquatic Vascular Plants: Edward Arnold, London, U.K., 610 p.

Stinner, D. H., 1983, Colonial Wading Birds and Nutrient Cycling in the Okefenokee Swamp. Okefenokee Ecosystems Investigations Technical Report \#13, Ph.D. Dissertation, University of Georgia, Athens, GA, $129 \mathrm{p}$.

Thorsen, J., 2002, personal communication, U.S. Forest Service, January 8.

Тотн, D. J., 1999, Water Quality and Isotope Concentrations from Selected Springs in the St. Johns River Water Management District: Technical Publication SJ99-2, St. Johns River Water Management District, Palatka, FL, 67 p.

Тотн, D. J., 2001, Nitrate concentrations in the Wekiva groundwater basin: Florida Scientist, Vol. 64, No. 1, p. 50.

Toth, D. J. And Fortich, C., 2002, Nitrate Concentrations in the Wekiva Groundwater Basin with Emphasis on Wekiva Springs: Technical Publication SJ2002-2, St. Johns River Water Management District, Palatka, FL, 76 p.

Tотн, D. J., 2003, Water Quality and Isotope Concentrations from Selected Springs in the St. Johns River Water Management District_Part 2: Technical Publication SJ2003-1, St. Johns River Water Management District, Palatka, FL, 67 p.

Тотн, J., 1963, A theoretical analysis of groundwater flow in small drainage basins: Journal Geophysical Research, Vol. 68, pp. 4795-4812.

U.S. Fish and Wildlife Service, 2001, Florida Manatee Recovery Plan, Third Revision: Southeast Region, U.S. Fish and Wildlife Service, Atlanta, GA, 144 p.

Vaithiyanathan, P. And Richardson, C., 1999, Macrophyte species changes in the Everglades: examination along a eutrophication gradient: Journal Environmental Quality, Vol. 28, pp. $1347-1358$.

Valiela, I.; Teal, J. M.; and Sass, W. J., 1975, Production and dynamics of salt marsh vegetation and the effects of experimental treatment with sewage sludge: Journal Applied Ecology, Vol. 12, pp. 973-981.

WaLSh, S. J., 2001, Freshwater macrofauna of Florida karst habitats. In Kuniansky, E. L. (Editor), Karst Interest Group Proceedings: U.S. Geological Survey Water-Resources Investigations Report 01-4011, pp. 78-88.

Wilcox, W. M.; Solo-Gabriele, H. M.; and Sternberg, L. O. 'R., 2004, Use of stable isotopes to quantify flows between the Everglades and urban areas in Miami-Dade County, Florida: Journal Hydrology, Vol. 293, pp. 1-19.

Zamora, C.; Kratzer, C. R.; Majewski, M. S.; and Knifong, D. L., 2003, Diazinon and Chlorpyrifos Loads in Precipitation and Urban and Agricultural Storm Runoff during January and February 2001 in the San Joaquin River Basin, California: U.S. Geological Survey Water-Resources Investigations Report 03-4091, 56 p. 